| ARTÍCULO

\title{
Tortura y malos tratos en la España democrática
}

\section{Torture and ill-treatment in democratic Spain}

\author{
Silvina Ribotta \\ Departamento de Filosofía del Derecho \\ Universidad Carlos III de Madrid
}

Fecha de recepción 22/04/2020 | De aceptación: 29/09/2020 | De publicación: 28/12/2020

\section{RESUMEN.}

La tortura en la España contemporánea y democrática es una realidad preocupante, como lo muestran Informes de los más relevantes organismos internacionales en la lucha y prevención de la tortura, como el Comité Europeo para la Prevención de la tortura del Consejo de Europa, ONG, sentencias internas del Estado español y, gravemente, sentencias del Tribunal Europeo de Derechos Humanos. Estas condenas a España del TEDH se producen por la violación del artículo 3 del Convenio Europeo de Derechos Humanos, por no realizar de manera exhaustiva y adecuada las investigaciones ante denuncias por malos tratos y torturas, y la última condena también por tratos inhumanos. Realidades que ponen al desnudo graves situaciones que exigen respuestas democráticas urgentes con acciones políticas, jurídicas y sociales directas e inmediatas, que impliquen contundente rechazo a las mismas y condena a sus responsables.

\section{PALABRAS CLAVE.}

Tortura, malos tratos, tratos inhumanos, prevención de la tortura, TEDH, impunidad

\section{ABSTRACT.}

Torture in contemporary and democratic Spain is a worrying reality, as shown by reports from the most relevant international organizations in the fight against and prevention of torture, such as the European Committee for the Prevention of Torture of the Council of Europe, NGO's, internal Spanish judgments and, grievously, judgments of the European Court of Human Rights. These sentences of the ECHR have found violations of article 3 of the European Convention on Human Rights, for not carrying out exhaustively and adequately the investigations into complaints of ill-treatment and torture, and in one case for inhuman treatment. These serious facts demand urgent democratic responses with direct and immediate political, legal, and social actions that imply the forceful rejection of them and the condemn of those responsible.

KEY WORDS.

Torture, ill-treatment, inhuman treatment, prevention of torture, ECHR, impunity 
Sumario: 1. Situando el análisis y la crítica; 2. La realidad que no puede ocultarse; 3. Los compromisos de España con la prohibición de la tortura; 4. Sentencias complejas y amenazas de impunidad; 5. Las condenas del Tribunal Europeo de Derechos Humanos; 6. Las deudas (democráticas) pendientes.

\section{Situando el análisis y la crítica.}

Hablar de tortura en España requiere precisar el cuándo, porque la tortura ha formado parte de la historia española durante siglos, incluso antes de que pudiéramos hablar de Estado español. Abolida oficialmente en España con la Constitución de 1812, tuvo su momento de horrendo esplendor en la dictadura de Francisco Franco, recordada como una de las más largas y más cruentas del mundo. Aunque quizá el mayor impacto de la tortura desde España lo ofreció la Inquisición española, con el desarrollo de la llamada tortura judicial y el auge de los Manuales de los Inquisidores, cuyos escrupulosos detalles pedagógicos de crueles maltratos se expandieron y utilizaron también en los territorios conquistados en América y, mucho después, en los entrenamientos a fuerzas de seguridad y paramilitares en la conocida como Escuela de las Américas, especialmente durante los años 70 y 80, y en los manuales de tortura que actualmente circulan y se utilizan, por ejemplo, en Guantánamo ${ }^{1}$.

Luego, con la llegada de la democracia a España, el marco político y jurídico de análisis de la tortura se modificó sustancialmente, especialmente desde la Constitución española de 1978 que prohíbe la tortura y los malos tratos de manera tajante en el artículo 15, cuando afirma sobre los derechos fundamentales y las libertades públicas que "todos tienen derecho a la vida y a la integridad física y moral, sin que, en ningún caso, puedan ser sometidos a tortura ni a penas o tratos inhumanos o degradantes...”. Pero, la cultura colectiva española de concienciación frente a la prohibición de la tortura y los malos tratos y la exigibilidad de mantenerla sin excepciones, ha encontrado un complejo reflejo en la carencia de genuinos procesos de justicia transicional sobre las gravísimas violaciones a los derechos

\footnotetext{
${ }^{1}$ Sobre estos complejos temas y sus relaciones, ver TOMÁS Y VALIENTE, Francisco, La tortura en España, Barcelona, Ariel, 1994 y “La última etapa y la abolición de la tortura judicial en España”, Anales de la Facultad de Derecho, No 1, 1963, pp. 23-60 y PETERS, Edward, La Tortura, traduc. Míguez, N., Madrid, Alianza, 1985. En concreto, sobre la vinculación de la Inquisición y las nuevas formas de tortura, ver GALVÁN RODRÍGUEZ, Eduardo, "La noche más oscura y el secreto inquisitorial" en FERNÁNDEZ RODRÍGUEZ, M., BRAVO DÍAZ, D., MARTÍNEZ PEÑAS, L. (coord.), Una década de cambios: de la guerra de Irak a la evolución de la primavera árabe (20032013), Madrid, Asociación Veritas para el Estudio de la Historia, el Derecho y de las Instituciones, 2013, pp. 83-98; ORTEGA GUERRA, Benjamín, "Biopolítica de la tortura: Guantanamizar Irak", Opera, No 8, pp. 7-55, particularmente 40-47; BUTLER, Judith, "El modelo Guantánamo", El Viejo topo, No 178, 2003, pp. 59-69; DEL BURGO, Myriam, "Guantánamo. Violación de los derechos humanos", Quadernos de criminología: revista de criminología y ciencias forenses, № 9, 2010, pp. 38-43; y BECK, Urich, Sobre el terrorismo y la guerra, Madrid, Paidós Asterisco, 2003. Sobre la conocida como Escuela de las Américas, recomendamos CIA, Human Resource Exploitation, Training Manual, 1983 y CIA, Human Resource Exploitation, Training Manual, 1982 en https://www.voltairenet.org/article121058.html o en http://www.soaw.org.
} 
humanos ocurridas durante los 40 años de dictadura franquista, que realmente permitieran justicia, verdad, memoria y reparación, no sólo para las víctimas de la dictadura sino también incluso para las de la llamada transición española ${ }^{2}$. Deudas a la justicia y a la memoria que siguen sin saldarse, incluso cuando se han abierto procesos en el exterior y se deniegan las extradiciones ${ }^{3}$.

A la vez, la historia democrática española que comenzó en los 80 estuvo marcada gravemente por la lucha contra el terrorismo interno, particularmente de ETA, hasta su disolución en 2018, y luego contra el terrorismo islamista, especialmente desde los atentados el 11 de marzo de 2004. Una lucha que no sólo tiñó de sangre y dolor la realidad de la vida en España, sino que trajo polémicas respuestas estatales, tanto policiales como judiciales con graves impactos en la vida democrática española y que han ocasionado relevantes sentencias del Tribunal Europeo de Derechos Humanos condenando a España por actos vinculados al artículo 3 del Convenio Europeo de Derechos Humanos, sobre prohibición de la tortura y tratos inhumanos y degradantes, y que han acompañado a condenas también del Tribunal Supremo y del Tribunal Constitucional español. Todo ello, en un clima mundial de lucha contra el terrorismo que ha puesto (y pone) en entredicho la prohibición erga omnes de la tortura y los tratos inhumanos y degradantes del derecho internacional, y que ha pasado desde el cuestionamiento velado (e incluso directo) a la prohibición de la tortura, a la defensa del uso de la misma bajo eufemismos lingüísticos como uso de la fuerza adecuado, legítima defensa o los "Enhanced Interrogation Techniques" instaurados por los Torture Memos del Gobierno de USA, hasta la directa y sin complejos reivindicación de la eficacia de la tortura ${ }^{4}$.

\footnotetext{
${ }^{2}$ Consultar ESCUDERO ALDAY, Rafael, Memoria histórica y democracia en España. La brecha de la Transición, México, Fontamara, 2016 y "Jaque a la Transición: análisis del proceso de recuperación de la memoria histórica", Anuario de Filosofía del Derecho, 2013 (XXIX), pp. 319-340; RUIZ-HUERTA, Alejandro, Los ángulos ciegos: Una perspectiva crítica de la transición española, 1976-1979, Madrid, Biblioteca Nueva, 2008; SAVATER, Fernando y MARTÍNEZ FRESNEDA, Gonzalo, Teoría y presencia de la tortura en España, Barcelona, Anagrama, 1982; SÁNCHEZ SOLER, Mariano, La transición sangrienta. Una historia violenta del proceso democrático en España (1975-1983), Barcelona, Península, 2010 y PÉREZ ROYO, Javier, Terrorismo, democracia y seguridad, en perspectiva constitucional, Madrid, Marcial Pons, 2010. Sobre las víctimas franquistas y de la transición: TOMÁS Y VALIENTE, Francisco, "García Valdés y Herrera de la Mancha", Diario 16, 29 octubre 1979; REVUELTA, Manuel, Herrera de la Mancha: Un caso ejemplar. Sumario 22/79, Madrid, Ediciones de la Piqueta, 1980; COLECTIVO 36, Libro blanco de las cárceles franquistas, Barcelona, Planeta, 2012 y NACIONES UNIDAS, Informe de Pablo de Greiff, Relator Especial sobre la promoción de la verdad, la justicia, la reparación y las garantías de no repetición, en la Misión España, A/HRC/27/56/Add.1, de 22 de julio de 2014.

3 Se recomienda la recién estrenada monografía colectiva de OLIVER OLMO, Pedro, LORENZO RUBIO, César, GARGALLO VAAMONDE, Luis, PARRA IÑESTA, Eduardo y OVIEDO SILVA, Daniel, La tortura en la España contemporánea, Los Libros de la Catarata, Madrid, 2020, que estudia la tortura en España desde principios del siglo XIX hasta la actualidad, siguiendo el testigo de la clásica obra de Francisco Tomás y Valiente.

${ }^{4}$ LA TORRE, Massimo, “Amistades peligrosas. Tortura y Derecho”, Derechos y Libertades, № 28, Época II, enero 2013, pp. 25-38 y LA TORRE, Massimo y LALATTA COSTERBOSA, Marina, ¿Legalizar la tortura? Auge y declive del Estado de Derecho, trad. de Ansuátegui Roig F., Valencia, Tirant Lo Blanch, 2018, especialmente pp. 133-195; GARCÍA CÍVICO, Jesús, "La doble ineficacia de la tortura", Cuadernos Electrónicos de Filosofía del Derecho, Número 34, 2016, pp. 134-161 y La tortura. Aspectos jurídicos, sociales y estéticos-

CEFD Número 43 (2020) I ISSN: 1138-9877 I https://doi.org/10.7203/CEFD.43.17577

c) (i) $(157$
} 
Este es el contexto temporal, histórico, político y cultural en el que sitúo este artículo: la situación actual de la tortura en el contexto democrático, particularizando el análisis en el Estado español. Partiendo, para ello, de la constatación judicial y política que en la España democrática contemporánea se producen casos de tortura, malos tratos, tratos inhumanos y degradantes. Estos, claramente, no constituyen una práctica sistemática, lo cual no sería necesario ni aclararlo, porque obviamente estamos hablando de un país democrático, pero existen y no son escasos, tal como muestra la casuística de Informes y sentencias como veremos a continuación, donde se exponen casos, denuncias y constataciones tanto de tortura o malos tratos directos, indirectos, o por ineficacia (¿dolosa?) procesal, que implica falta de investigaciones exhaustivas de las denuncias, y muestra cierto desprecio por el rigor de las denuncias y por la credibilidad de las víctimas, lo que no resulta propio de una democracia moderna. Y resultan, por ello mismo, altamente preocupantes para toda persona que se precie democrática y que pretenda defender la democracia española. Y son, a todas luces, injustificables.

Para ello, en el presente artículo revisaré primero los compromisos jurídicos realizados por España a nivel internacional en la lucha contra la tortura y las plasmaciones de dichos compromisos en el derecho penal interno. Para, luego, analizar sentencias de los órganos jurisdiccionales españoles que ponen en entredicho la eficacia del ordenamiento jurídico específico de prohibición de la tortura y muestran señales serias de impunidad, hasta llegar a las 10 sentencias del Tribunal Europeo de Derechos Humanos que condenan a España por violación del artículo 3 del Convenio Europeo de Derechos Humanos.

\section{La realidad que no puede ocultarse.}

Podemos encontrar diversos informes y condenas que muestran la gravedad de los hechos que ocurren en España en relación a las torturas y los malos tratos.

El Comité contra la Tortura de las Naciones Unidas ha determinado en dos casos que España ha violado la Convención contra la Tortura por investigaciones inadecuadas ante denuncias de malos tratos y tortura a personas con detención incomunicada, uno cometido por miembros de la Guardia Civil en

culturales, Valencia, Tirant lo Blanch, 2019, especialmente pp. 12-22 y 118-200. Sobre Enhanced Interrogation Techniques y Torture Memos, también: https://www.businessinsider.com/the-13-enhanced-interrogation-techniques-the-cia-used-on-detainees-2014-12?IR=T 
Madrid $^{5}$ y otro en el País Vasco ${ }^{6}$, similar a lo que en 2013 determinó el Comité de Derechos Humanos de las Naciones Unidas?

Existen también distintos Informes del Comité Europeo para la Prevención de la tortura y de las penas o tratos inhumanos o degradantes del Consejo de Europa (CPT) que han sido dirigidos al Gobierno español denunciando torturas y malos tratos, incluso torturas sexuales severas, y donde se realizan relevantes recomendaciones sobre las personas en detención incomunicada y los informes que realizan los médicos forenses ${ }^{8}$. También hay un Informe de 9 de octubre de 2013 emitido por el Comisario de Derechos Humanos del Consejo de Europa especialmente interesado por las repercusiones de la crisis económica y las medidas de austeridad fiscal, y donde considera ilícito e injustificable que la policía realice interrogatorios a presuntos culpables o a sus abogados portando capuchas para no ser identificados ${ }^{9}$. Especialmente relevante es el Informe que preparó el CPT para el gobierno español luego de la visita llevada a cabo del 27 de septiembre al 10 de octubre de 2016 a ocho comisarías, seis cárceles y dos centros de menores, donde se hace constar una relevante cantidad de denuncias sobre maltrato físico de personas detenidas en módulos de régimen cerrado y departamentos especiales, todas documentadas con informes médicos, donde detalla torturas y malos tratos como castigo informal por haber desobedecido alguna orden o indicación o luego de disturbios o peleas entre internxs, en el momento de la detención o en la llegada a la comisaría ${ }^{10}$. El Comité constata, también documentados

\footnotetext{
${ }^{5}$ Dictamen del Comité contra la Tortura en virtud del artículo 22 de la Convención contra la Tortura y Otros Tratos o Penas Crueles, Inhumanos o Degradantes, en el caso Encarnación Blanco Abad c. España, Comunicación No 59/1996, U.N. Doc. CAT/C/20/D/59/1996 (1998). El Comité advierte que las autoridades tienen la obligación de iniciar una investigación ex oficio siempre que haya motivos razonables para creer que actos de tortura o malos tratos han sido cometidos, y que la investigación debe ser imparcial y urgente, para evitar que la víctima pueda continuar siendo sometida a malos tratos y porque las huellas físicas de la tortura y malos tratos pueden desaparecen en corto plazo (párrafo 8.2).

${ }^{6}$ Caso Oskartz Gallastegi Sodupe c. España, Comunicación № 453/2011, U.N., Doc. CAT/C/48/D/453/2011, en el cual el Comité contra la Tortura estima que hay violación del artículo 12 de la Convención, ya que hay una ausencia injustificada de actividad investigativa por parte de las autoridades españolas (párrafo 7.3).

${ }^{7}$ Caso María Cruz Achabal Puertas c. España, Comunicación No 1945/2010, U.N. Doc. CCPR/C/107/D/1945/2010 (2013), El Comité de Derechos Humanos actuando en virtud del Protocolo Facultativo al Pacto Internacional de Derechos Civiles y Políticos reconoce que existió violación del artículo 7 en relación con el artículo 2 párrafo 3 del Pacto, en relación a la posibilidad de la demandante de interponer un recurso efectivo en caso de maltrato o tortura y a que las autoridades competentes, ya sea judiciales, administrativas o legislativas actúen adecuadamente sin denegación de justicia.

${ }^{8}$ Ver Informes del Comité Europeo para la prevención de la tortura y de las penas o tratos inhumanos o degradantes-CPT sobre las visitas llevada a cabo en España en julio de 2001 (informe del 13 de marzo del 2003), en diciembre de 2005 (informe del 10 de julio de 2007) y de entre mayo y junio de 2011 (informe del 30 de abril de 2013).

${ }^{9}$ CONSEJO DE EUROPA, Informe Comisario para los Derechos Humanos del Consejo de Europa - Nils Muižnieks, tras su visita a España, del 3 al 7 de junio de 2013, de 9 de octubre de 2013, p. 32.

${ }^{10}$ CPT, Informe para el Gobierno español sobre la visita llevada a cabo en España del 27 de septiembre al 10 de octubre de 2016 , especialmente pp. 5 a 10.
} 
con informes médicos, la existencia de bofetadas, puñetazos, patadas, golpes con porras y largas e injustificadas sujeciones mecánicas que en algunos casos han durado días, sin ningún tipo de supervisión ni registro adecuado, y que en varios centros penitenciarios se imponían períodos consecutivos de hasta 14 días de aislamiento con fines disciplinarios. El Informe detalla situaciones especialmente violentas con personas que se encuentran en condiciones de mayor vulnerabilidad, como personas con discapacidades mentales o sensoriales, mujeres o prisionerxs ${ }^{11}$ transgénero. Respecto al caso de menores, el Comité denuncia el uso de la sujeción mecánica para los mismos y que se imponga aislamiento disciplinario. Y, aunque la legislación española estipula un máximo de aislamiento de siete días para un menor, medida que el Comité ya considera excesivo, constata la situación de menores que habían sido sometidxs a aislamiento como medida disciplinaria durante tres periodos consecutivos ${ }^{12}$. A su vez, señala que las personas en régimen de detención incomunicada no estaban asistidas por abogadx de su elección, sino por un abogadx de oficio, y en algunos casos sin derecho a poder hablar con éste. También expone tratos degradantes desde las mismas instalaciones, donde no se garantiza adecuada ventilación, luz, ni limpieza. El Comité también llama la atención sobre la falta de registro y notificación adecuado de las lesiones en todos los centros visitados, donde lxs médicos de las prisiones demostraron, en general, una actitud reacia a registrar y notificar los episodios de supuestos malos tratos, especialmente hematomas lineales y fracturas. Y manifiesta su preocupación por el hecho de que muy pocos procedimientos penales por denuncias de maltratos lleguen a la fase final de investigación, alertando sobre la sensación de impunidad, la ausencia o la calidad deficiente de los registros médicos, la falta de información, los traslados forzosos luego de las denuncias, el archivo de demandas, entre otras acciones que minan la confianza de lxs internxs en la efectividad e imparcialidad del sistema de denuncias.

Estas situaciones, o parte de ellas, pueden encontrarse también en distintos Informes y estudios oficiales españoles, como el Informe monográfico que encargó especialmente el Defensor del Pueblo español como Mecanismo Nacional de Prevención de la Tortura, el Estudio sobre los partes de lesiones de las personas privadas de libertad de 2014, que incluye también pruebas fotográficas de informes de

\footnotetext{
${ }^{11}$ En adelante utilizaré la "X" como marcador de género neutro e inclusivo.

12 Igualmente, el Comité da cuenta que ha encontrado en las oficinas de los inspectores de la Policía Nacional, utilizadas para el interrogatorio de sospechosxs de algunas de las comisarías visitadas, objetos completamente extraños y difícilmente explicables, como palos, bates de béisbol, látigo y cuerda/soga, lo que invita a especular sobre un comportamiento impropio por parte de los agentes. Ídem, p. 16.
} 
lesiones incompletos o con escasa información en la inspección de los centros penitenciarios ${ }^{13}$. Y donde se realizan recomendaciones específicas a la Subdirección de Inspección Penitenciaria, como el que todos los servicios sanitarios penitenciarios elaboren informes de lesiones cada vez que hay denuncias de malos tratos, que se garantice la confidencialidad de los reconocimientos médicos de las víctimas y la obligación médica de notificar directamente a las autoridades judiciales pertinentes sus conclusiones y su evaluación. Y, muy relevante, que el personal policial y penitenciario deje de recurrir de manera rutinaria a la fijación mecánica. De modo similar, también se pueden consultar los Informes anuales de la Fiscalía General del Estado donde constan las estadísticas de las denuncias de tortura y otros malos tratos a manos de funcionarixs.

Y, por supuesto, los Informes de Organismos Internacionales y de ONG que denuncian casos de tortura y tratos degradantes, especialmente en personas en situación de mayor vulnerabilidad como extranjerxs, personas con discapacidad, mujeres o niñxs. Investigaciones como las que presentan el Informe 2017/2018 Amnistía Internacional. La situación de los derechos humanos en el mundo, el Informe España ante la tortura y los malos tratos de noviembre 2016 de la Fundación Abogacía Española, el Informe de Human Right Watch 2017 o la Recopilación de las denuncias por tortura, violencia institucional y tratos inhumanos, crueles o degradantes recogidos durante el año 2017 en el Estado español realizado por la Coordinadora para la Prevención y Denuncia de la Tortura ${ }^{14}$.

Un tema de especial relevancia lo constituyen los Centros de Internamiento de Extranjeros- CIE, lugares donde se priva de la libertad a personas migrantes que tienen una situación administrativa irregular. Quienes, sin haber cometido ningún delito ni falta, son privados de la libertad en muchos casos en condiciones inhumanas, hacinados, sin servicios médicos o atenciones ante necesidades especiales, sin poder acceder a servicios de salud, educación u ocio, y atendidos por personal no cualificados. Muestran estas dramáticas situaciones diversos informes, como el Informe anual 2017. Sobre el racismo en el Estado español de SOS Racismo, donde se recogen las denuncias de múltiples organizaciones sobre

\footnotetext{
${ }^{13}$ DEFENSOR DEL PUEBLO, Informe monográfico Estudio sobre los partes de lesiones de las personas privadas de libertad, Madrid, mayo 2014, especialmente pp. 19-25. Y ver MECANISMO NACIONAL ESPAÑOL DE PREVENCIÓN DE LA TORTURA-DEFENSOR DEL PUEBLO, Informe anuales 2018, Madrid, 2019.

14 AMNISTÍA INTERNACIONAL, Informe 2017/2018 Amnistía Internacional. La situación de los derechos humanos en el mundo, Londres, 2018; FUNDACIÓN ABOGACÍA ESPAÑOLA, Informe España ante la tortura y los malos tratos de noviembre, Madrid, 2016; HUMAN RIGHT WATCH, Informe Human Right Watch 2017, NY, 2018 y COORDINADORA PARA LA PREVENCIÓN Y DENUNCIA DE LA TORTURA, La tortura en el Estado español. Recopilación de las denuncias por tortura, violencia institucional y tratos inhumanos, crueles o degradantes recogidos durante el año 2017 en el Estado español, mayo 2018; entre otros.
} 
el tratamiento que reciben migrantes en los CIE, denunciando graves situaciones de maltrato, hacinamiento, falta de asistencia médica, maltrato psicológico y físico y algunas muertes en circunstancias de, al menos, falta de atención médica adecuada ${ }^{15}$. También hubo distintos motines y fugas en CIE de toda España, denunciando las duras condiciones estructurales, los maltratos psicológicos y físicos y las violaciones a los derechos humanos más básicos. El CIE de Aluche, en Madrid, es el que más denuncias acumula de España ${ }^{16}$.

Por consiguiente, hay serias constancias de situaciones graves que constituyen maltrato o torturas, tanto de manera directa como indirecta por las condiciones en que se encuentran las personas privadas de su libertad por diferentes causas, tanto en instituciones policiales y de las fuerzas y cuerpos de seguridad, como en prisiones, CIE, Centros de Menores, hospitales psiquiátricos, entre otros. Casuística que se suele asociar a la lucha contra el terrorismo, especialmente de ETA, ya que gran parte de las sentencias del Tribunal Europeo de Derechos Humanos vinculadas a tortura se refieren a causas de terrorismo. Esta vinculación también forma parte de un discurso justificador o minimizador de la tortura instaurado en la conciencia colectiva para asociar torturas a manipulación terrorista, y persona terrorista (o semejante, real o presunto) como un sujeto que resulta torturable; ya que la realidad nos muestra otra cara que no queremos ver sobre los malos tratos en España, y que tiene que ver con la situación en la que se encuentran los sectores más desfavorecidos y con mayor vulnerabilización socio-estructural, como migrantes en situación irregular, mujeres y niñas, personas con discapacidad, niñxs migrantes y migrantes no acompañados y, particularmente cuando se encuentran desaventajados económicamente, viviendo en situaciones de pobreza, lo que aumenta la vulnerabilización en la que sobreviven, porque no poseen recursos adecuados, tanto económicos, jurídicos, culturales o de redes sociales, para realizar denuncias, visibilizar sus realidades y, mucho menos, para poder litigar ante el Tribunal Europeo de Derechos Humanos, al que llegan muy pocos $\operatorname{casos}^{17}$. Aunque las 10 sentencias que condenan a España

\footnotetext{
${ }^{15}$ Ver diferentes casos de malos tratos en distintos CIE's españoles en SOS RACISMO, Informe anual 2017. Sobre el racismo en el Estado español, Donostia/San Sebastián, 2017, pp. 107-118 y AMNISTÍA INTERNACIONAL, España. Crisis de identidad: Tortura y malos tratos por motivos racistas a manos de agentes del Estado, Londres, 2002.

${ }^{16}$ Situaciones de graves violaciones de derechos humanos que han sido también denunciadas públicamente hasta por el mismo Magistrado Ramiro García de Dios Ferreiro, quien estuvo al frente del Juzgado de Instrucción Número 6 de Madrid durante 30 años hasta su retito en 2018 y ha sido juez de control del CIE de Aluche en sus últimos ocho años.

${ }^{17}$ Consultar la "Guía práctica destinada a abogados que representen a demandantes antes el Tribunal Europeo de Derechos Humanos", elaborada por el Consejo de la Abogacía Europea, donde se admite las dificultades económicas y de acceso para poder llegar a plantear un recurso ante el TEDH, donde "la cantidad asignada en concepto de asistencia jurídica es relativamente escasa y sólo representa un porcentaje bajo de las costas procesales". CONSEJO DE LA ABOGACÍA EUROPEA-CCBE, Tribunal Europeo de Derechos Humanos. Preguntas y respuestas para los abogados, 2012, especialmente pág. 12 .
} 
siguen siendo un relevante llamado de atención que una sociedad democrática no puede ignorar y deberían funcionar como activadores del compromiso genuino que España tiene con la prohibición de la tortura y los malos tratos; entendiendo que desnudar las estructuras de impunidad de los malos tratos y la tortura, instrumentar y hacer efectiva la prevención de los mismos y condenar de manera contundente cuando se producen, debería ser una política de Estado prioritaria.

\section{Los compromisos de España con la prohibición de la tortura.}

España ha ratificado todos los instrumentos más relevantes de Derecho Internacional y de Derecho Europeo respecto a la prohibición de la tortura y los tratos inhumanos y degradantes, y también respecto a la prevención de los mismos, que resultan de aplicabilidad directa dentro del Ordenamiento jurídico español. De entre los más relevantes, la Declaración Universal de Derechos Humanos de 1948 (artículo 5), el Convenio Europeo para la Protección de los Derechos y de las Libertades Fundamentales de 1950 (artículo 3), el Pacto Internacional de Derechos Civiles y Políticos (artículo 7 y 10.1), la Convención de las Naciones Unidas sobre los Derechos del Niño (artículo 37 y 39), la Carta de Derechos Fundamentales de la Unión Europea del año 2000 (artículo 4) y la Convención de las Naciones Unidas sobre los Derechos de las Personas con Discapacidad (artículo 15). Y, en concreto, la Convención de las Naciones Unidas contra la Tortura y otros tratos o penas crueles, inhumanas y degradantes de 1984, el Convenio Europeo para la Prevención de la Tortura y de las penas o tratos crueles, inhumanos y degradantes de 1987 y el Protocolo Facultativo a la Convención contra la Tortura ${ }^{18}$. Muy relevante este último, cuyo especial énfasis es la prevención de la tortura, y que coordina acciones de un mecanismo internacional diferente a los que ya existen en el seno de Naciones Unidas, el Subcomité para la Prevención de la Tortura y Otros Tratos Crueles, Inhumanos o Degradantes, y mecanismos internos de cada Estado, con el objetivo de establecer un sistema de visitas periódicas a todos los lugares donde se encuentren personas privadas de su libertad para prevenir tortura y malos tratos. Por este Protocolo, se instauró en España el Mecanismo Nacional de la Tortura español (MNPT) que funciona dentro del

\footnotetext{
${ }^{18}$ España ratificó el 21 de octubre de 1987 la Convención contra la tortura y otros tratos crueles o penas crueles, inhumanos o degradantes, el 28 de abril de 1989 el Convenio Europeo de 26 de noviembre de 1987 para la Prevención de la Tortura y el 4 de abril de 2006 el Protocolo Facultativo a la Convención contra la Tortura.
} 
Defensor del Pueblo y que juega un rol altamente valioso en la prevención de la tortura y en políticas públicas para fortalecer medidas destinadas a ello ${ }^{19}$.

En relación con estos instrumentos internacionales, el ordenamiento jurídico español prohíbe de manera concluyente la tortura y los malos tratos, tanto desde el artículo 15 de la Constitución española ${ }^{20}$ como del propio Código Penal español-CP que le dedica todo un Título donde integra distintos delitos, y en cuya reforma tuvo un relevante impacto la propia Convención. El Título VII del CP: De las torturas y otros delitos contra la integridad moral comienza con el delito de trato degradante, artículo 173, e incluye el delito de violencia habitual intrafamiliar, delito de acoso laboral y asedio inmobiliario, y el artículo 174 que trata directamente el delito de tortura; mientras el 175 se refiere a los delitos contra la integridad moral no incluidos en los artículos 173 ni 174, y deja para el artículo 176 y 177 la regla de la omisión en las torturas y la regla concursal. Como se ha criticado en distintos estudios, el CP utiliza una técnica legislativa confusa, que incluye a la tortura dentro de los delitos que menoscaban el bien jurídico de la integridad moral y que, aparte de tipificar la tortura en su modalidad indagatoria como gratuita (artículo 174 y 175), introduce el atentado contra la integridad moral en el artículo $173^{21}$.

Respecto al concreto delito de torturas, el CP lo recoge como delito autónomo y como delito especial, recogiendo el mandato de la Convención contra la Tortura de Naciones Unidas y el Convenio Europeo para la prevención de la tortura, y lo define de manera similar, exigiendo la especial cualificación del sujeto activo que realiza la conducta típica, una autoridad o funcionarix públicx, pero especificando que la acción la realice abusando de su cargo y aprovechándose de la dependencia o

\footnotetext{
${ }^{19}$ El MNP de la Tortura se reguló en España a través de la Ley Orgánica 1/2009, de 3 de noviembre, añadiendo una Disposición Final Única a la Ley Orgánica 3/1981, de 6 de abril del Defensor del Pueblo, designando en exclusiva al Defensor del Pueblo como Mecanismo Nacional, creándose en su interior la Unidad del Mecanismo Nacional de Prevención de la Tortura. MARIÑO MENENDEZ, Fernando y CEBADA ROMERO, Alicia (dir.), La creación del mecanismo español de prevención de la tortura, Madrid, Iustel, 2009; PINO GAMERO, Esther, "El sistema de prevención de la tortura del Protocolo Facultativo a la Convención contra la Tortura", Universitas. Revista de Filosofia, Derecho y Política, No 18, Julio 2013, pp. 3-39 y RIBOTTA, Silvina, "Sobre el Protocolo Facultativo a la Convención contra la Tortura y su regulación en el derecho español. Mejor prevenir que castigar”, ICADE. Revista de las Facultades de Derecho y Ciencias Económicas y Empresariales, № 85, 2012, pp. 153-180.

${ }^{20}$ RIBOTTA, Silvina, "La Tortura en la Constitución española”, en DE LUCAS, J. y RODRÍGUEZ URIBES, J.M. (editores), La Constitución de 1978 y los derechos humanos, Valencia, Tirant lo Blanch, 2018, pp. 413-446.

${ }^{21}$ MUÑOZ SÁNCHEZ, Juan, Los delitos contra la integridad moral, Valencia, Tirant lo Blanch, 1999; TAMARIT SUMALLA, Josep María, "De las Torturas y otros delitos contra la integridad moral" en QUINTERO OLIVARES, G. (Director) y MORALES PRATS, F. (Coordinador), Comentarios al Código Penal Español. Tomo I (Artículos 1 a 233), Navarra, Thomson Reuters-Aranzadi, $2011,6^{\circ}$ edición, pp. 1059-1092; DÍAZ PITA, María del Mar, "El bien jurídico protegido en los nuevos delitos de tortura y atentado contra la integridad moral”, Estudios Penales y Criminológicos, No 20, 1997, p. 37; ZÚÑIGA RODRÍGUEZ, Laura, "El tipo penal de tortura en la legislación española, a la luz de la jurisprudencia nacional e internacional”, UNIVERSITAS VITAE homenaje a Ruperto Núñez Barbero, Universidad de Salamanca, 2014, pp. 898-945, especialmente p. 911.
} 
sometimiento en la que se encuentra el sujeto pasivo. Y no se refiere a funcionarix públicx en términos genéricos $^{22}$, sino a funcionarixs y cuerpos policiales, de la administración de justicia, de la administración penitenciaria, o centros de protección o corrección de menores o afines (artículo 174.2), en el ejercicio de sus funciones y abusando de su cargo; con lo cual incluye a autoridades o funcionarixs públicxs que tengan encomendada alguna función en la cual puedan abusar, que suelen ser las vinculadas a la investigación y persecución de delitos. De esta manera, al exigir que actúe abusando de su cargo, ejerciendo la función y el servicio de orden público que debía cumplir, restringe las personas que pueden tener la consideración de sujeto activo de tortura porque impone mayores exigencias que la propia Convención, excluyendo a la persona que actúa por móviles privados y no abusando del cargo ${ }^{23}$. Pero completa, a su vez, otra de las exigencias de la Convención al punir cuando la autoridad permitiere que otras personas ejecuten la tortura (artículo 176), configurando un delito de comisión por omisión y no de omisión propia, castigando la cooperación omisiva a un hecho típico enmarcada en los deberes de supervisión y vigilancia propios de la actividad delegada de una autoridad o funcionarix públicx equiparando la acción misma con la omisión ${ }^{24}$.

En relación al elemento material del tipo, exige la conducta de someter al sujeto pasivo a condiciones o procedimientos que debido a la duración, naturaleza o circunstancias conlleven sufrimientos físicos o mentales, supresión o disminución de las facultades de conocimiento, discernimiento o decisión o que, de cualquier otro modo, atenten contra la integridad moral del mismo. De este modo, considera tanto a los sufrimientos morales, mentales o psicológicos, al igual que la Convención, pero es más incluyente al referirse directamente a la supresión o disminución de las facultades de conocimiento, discernimiento o decisión y, esencialmente, al no exigir que los sufrimientos físicos o mentales sean graves.

Respecto a la finalidad, se exige que la acción típica busque obtener una confesión o información de cualquier persona o de castigarla por cualquier hecho que haya cometido o se sospeche que ha

\footnotetext{
${ }^{22}$ Artículo 24.2 de la CE: "Se considerará funcionario público todo el que por disposición inmediata de la Ley o por elección o por nombramiento de autoridad competente participe en el ejercicio de funciones públicas".

${ }^{23}$ DÍAZ PITA, María del Mar, "El bien jurídico protegido en los nuevos delitos de tortura y atentado contra la integridad moral", citado, pp. 42 y 43.

24 TAMARIT SUMALLA, Josep María, "De las Torturas y otros delitos contra la integridad moral”, citado, p. 1088. La jurisprudencia ha equiparado en las penas a quienes materialmente torturan y a los superiores que lo permiten, debido a su deber de vigilancia y jerarquía. Ver STS 19 de diciembre 1996-RJ 1996, 9010 y STS 18 de julio 1997-RJ 1997, 6069.
} 
cometido, o por cualquier razón basada en algún tipo de discriminación, contemplando la llamada tortura indagatoria (para obtener información o confesión o como castigo) y la tortura gratuita (basada en cualquier otro tipo de discriminación). Vuelve, por lo tanto, a resultar más restrictivo que la Convención al excluir los supuestos de tortura de terceros, que se configuran cuando se aplica la tortura a una persona para conseguir la declaración de otra, porque exige identidad entre el torturado y aquel de quien se pretende obtener información, confesión o a quien se pretende castigar ${ }^{25}$. A la vez, el tipo subjetivo exige la comisión dolosa más un elemento subjetivo del injusto, vinculado a los fines de obtener una información o testimonio o de castigar al sujeto pasivo por cualquier hecho que haya cometido o se sospeche que haya cometido.

Otra de las peculiaridades de la regulación del CP español radica concretamente en la sanción, donde estipula pena de prisión de dos a seis años si el atentado fuera grave y de prisión de uno a tres años si no lo es, más la pena de inhabilitación absoluta de ocho a 12 años. Regulación diferente a la propia Convención contra la Tortura que exige que los sufrimientos impliquen dolores graves, mientras que el $\mathrm{CP}$ diferencia entre un delito de tortura grave y otro que no lo es, lo que ha sido ampliamente criticado $^{\mathbf{2 6}}$. El propio Comité contra la Tortura ha señalado a España en varias ocasiones que tiene que garantizar que todos los casos de tortura sean considerados de carácter grave, como carácter indisoluble e intrínseco de concepto mismo de tortura ${ }^{27}$. Lo relevante de la tipificación es que el daño debe ser grave y objetivable, aunque la gravedad de la acción la gradúa en los tipos penales en relación a la sanción, distinguiendo entre atentados más y menos graves entre las distintas penas en el delito de trato degradante (artículo 173) a las distintas penas en el delito de tortura (artículo 174). Según jurisprudencia del Tribunal Supremo, este daño puede crear en las víctimas sentimientos de terror, inferioridad y humillación, quebrar su resistencia física o moral, resultar vejatorio e implicar un padecimiento físico o psíquico

\footnotetext{
${ }^{25}$ Aunque si entre la víctima directa de tortura y el tercero hay relación de parentesco o de afectividad que implique sufrimiento mental o moral del mismo torturado se podría aplicar el tipo de tortura. Ver TAMARIT SUMALLA, Josep María, "De las Torturas y otros delitos contra la integridad moral", citado, pp. 1083-1084.

${ }^{26} \mathrm{El} \mathrm{CP}$ español no estructura los tipos penales tortura, tratos inhumanos y tratos degradantes siguiendo el criterio de gradualidad que establece el Derecho Internacional y confirma la doctrina del TEDH y del TC española (STC 120/1990 y STC 137/1990). ZÚÑIGA RODRÍGUEZ, Laura, "El tipo penal de tortura en la legislación española, a la luz de la jurisprudencia nacional e internacional", citado, p. 913.

27 “Observaciones finales del Comité contra la Tortura" relativas a España, de 9 de diciembre de 2009, párrafo 8 apartado C, "Principales motivos de preocupación y recomendaciones". Díaz Pita critica esta división bipartita en la consideración de la gravedad del trato infligido al sujeto pasivo: DÍAZ PITA, María del Mar, "El bien jurídico protegido en los nuevos delitos de tortura y atentado contra la integridad moral", citado, p. 94-95. Contrastar con STS de 27 de noviembre de 2012, FD $4^{\circ}$ y ORTIZ DE URBINA, Iñigo, "Sobre el delito de tortura en el CP español”, inédito, 2018.
} 
relevante $^{28}$, e implicar una única conducta puntual y aislada o requerir varias conductas que produzcan un daño relevante al ocurrir de manera sistemática o reiterada ${ }^{29}$.

A la vez, completa la regulación con otras figuras delictivas residuales (artículo 175) que conlleva la acción típica de atentar genéricamente contra la integridad moral aunque el fin no incluya el elemento subjetivo de obtener una confesión o información o castigar por cualquier hecho que haya cometido o se sospeche que ha cometido, o por cualquier razón basada en algún tipo de discriminación, siempre que sean cometidos por funcionarix públicx o autoridad y con abuso de su cargo ${ }^{30}$. O diseñando un tipo penal común aplicable a quienes realizan la misma o similar conducta y no son autoridad o funcionarixs públicxs (artículo 173), admitiendo la autoría mediata en aquellos actos que el poder político ejecuta la tortura a través de particulares. Muy polémico y poco práctico es la inclusión de este delito de tipo penal común que pone el eje de protección en un derecho fundamental como la integridad moral, que se configura entre particulares, que se puede desarrollar en el ámbito laboral, familiar o de una superioridad fáctica producto de una desigualdad de fuerzas o del número de personas presentes. Más aún, produce confusión respecto a la acción, al mezclar las categorías que el Derecho internacional entiende como conductas que van agravando los malos tratos, del trato degradante al trato inhumano, y de éste a la tortura $^{31}$; ya que el delito de trato degradante implica menoscabo grave a la integridad moral combinando la conducta que expresa la menor gravedad en la escala de Derecho internacional (trato degradante) pero con la exigencia de que esta produzca una lesión grave a la integridad moral del sujeto pasivo ${ }^{32}$. El sujeto que ejecuta la acción no es funcionarix públicx ni persigue el elemento teleológico que se exige para el tipo de tortura, aunque el tipo exige infligir a una persona un resultado lesivo de menoscabo grave de su integridad moral y la intencionalidad dolosa de hacerlo, resultando difícilmente admisible el dolo

${ }^{28}$ STS 1218/2004-RJ 2004|8007; STS 1122/1998-RJ 199817370 y STS 294/2003-RJ 2003.

${ }^{29}$ STS 819/2002-RJ 200216709 y STS 489/2003-RJ 2003\4007. Como ejemplos de la jurisprudencia en relación a la gravedad del atentado a la integridad moral: policía que priva al detenido ilegalmente de su derecho de defensa (tortura no grave en STS 1202/1995-RJ 1995, 8879), detenido vendado y encapuchado, electrodos en manos, golpes repetidos, amenazas (tortura en STS 481/2003-RJ 2003, 3490), graves golpes por resistencia a la autoridad (delito contra la integridad moral en STS 294/2003-RJ 2003, 4381), obligar a desnudarse y hacer ejercicios físicos (trato degradante en STS 457/2003-RJ 2003, 8929).

${ }^{30} \mathrm{Y}$ que algunos analizan como una cualificación del delito de trato degradante del artículo 173. Ver MUÑOZ CONDE, Francisco, Derecho Penal. Parte Especial, Valencia, Tirant lo Blanch, 2002, pp. 184 y sig.; MUÑOZ SÁNCHEZ, Juan, Los delitos contra la integridad moral, citado, pp. 20 y sig.

${ }^{31}$ TAMARIT SUMALLA, Josep María, “De las Torturas y otros delitos contra la integridad moral”, citado, p. 1063.

${ }^{32}$ DÍAZ PITA, María del Mar, "El bien jurídico protegido en los nuevos delitos de tortura y atentado contra la integridad moral", citado, p. 51. Es verdad, explica la autora, que el Derecho Penal tiene independencia del Derecho internacional, pero la expresión es confusa. El legislador podría haber utilizado mejor la expresión de "trato inhumano" que aparece más claro como segundo escalón de gravedad. 
eventual, pese a que no se requiere la presencia de un ánimo específico o de una actitud interna especialmente concreta o de una motivación especial, con lo cual reproduce los problemas habituales de indeterminación al delegar absolutamente en los Tribunales la valoración de la gravedad de la conducta típica $^{33}$. Del mismo modo, siendo permeable a las diversas formas de maltratos y acosos que se producen en las modernas realidades sociales, el CP ha ido incluyendo con sucesivas reformas a conductas que implican claramente trato degradante, como los nuevos delitos de acoso escolar cuando tengan la gravedad suficiente que requiere el tipo, el delito de violencia habitual intrafamiliar, el delito de acoso laboral y el delito de asedio inmobiliario ${ }^{34}$.

De esta manera, con una técnica legislativa problemática y criticada, el CP español deja clara la prohibición de la tortura; aunque las diferencias entre la regulación del CP en relación a las exigencias de la Convención, deberían considerarse para posibles modificaciones legislativas ${ }^{35}$. El Derecho Penal español, en efecto, incluye de manera contundente la prohibición de la tortura y de los tratos degradantes, cubriendo un abanico amplio de la casuística, protegiendo la integridad moral y prohibiendo la tortura y los maltratos en todas sus formas y por todos los sujetos. Y aunque la forma de tipificar los delitos y la técnica legislativa puede (y debería) ser mejorada, el Código Penal no sólo es directo en la prohibición y en la regulación, sino que es incluyente de las diferentes posibilidades contemporáneas en las que se pueden producir malos tratos, tanto de funcionarixs de fuerzas y cuerpos de seguridad del Estado, del servicio penitenciario y vinculados, como en los tipos penales de ciudadanos privados. Sin duda, los casos de tortura y tratos degradantes que se producen en España están, radical y ampliamente, condenados como delitos.

\section{Sentencias complejas y amenazas de impunidad.}

Consecuencia de la legislación penal, hay numerosas sentencias dictadas en España que condenan

\footnotetext{
33 TAMARIT SUMALLA, Josep María, “De las Torturas y otros delitos contra la integridad moral”, citado, p. 1065.

${ }^{34}$ Incorporados en 2010, por Ley Orgánica 5/2010 de 22 de junio. Ver TAMARIT SUMALLA, Josep María, "De las Torturas y otros delitos contra la integridad moral", citado, p. 1076.

${ }^{35}$ Podrían distorsionar las estadísticas comparativas de delitos de tortura e impactar en los Informes que los Estados parte de la Convención contra la tortura deben presentar de forma periódica ante el Comité contra la Tortura, como señala Ortiz de Urbina; ya que estaríamos comparando estadísticas sobre casos que son tortura para el CP español y no lo son para la Convención y a la inversa. ORTIZ DE URBINA, Iñigo, "Sobre el delito de tortura en el CP español", citado.
} 
por trato degradante o tortura, tanto del Tribunal Supremo ${ }^{36}$ como pronunciamientos destacables del Tribunal Constitucional ${ }^{37}$. Lo que debería resultar obvio es que las obligaciones que los Estados asumen respecto a cuestiones sustanciales y procesales en la prohibición de la tortura y los malos tratos, tendrían que trasladarse de manera directa a la efectividad de las normas jurídicas y las políticas públicas al respecto. Obviamente, los compromisos adquiridos internacionalmente en la prohibición y prevención de la tortura y los tratos inhumanos y degradantes no eliminan toda posibilidad de que se produzcan actos de tortura, tratos inhumanos o degradantes dentro del Estado, pero hay un radical impacto positivo (o no) según la generación y adaptación de las normas internas de cada Estado a los requerimientos internacionales adoptados, la producción y efectividad de políticas públicas al respecto, la aplicación de las normas jurídicas de manera adecuada y oportuna, y los políticas de prevención de la tortura implementadas. La diferencia radica, gravemente, en la reacción de los países cuando se produce un hecho de tortura o malos tratos, entre aquellos que investigan exhaustivamente los hechos hasta llegar a los autores, les condenan por los delitos cometidos e instauran las medidas adecuadas para la prevención de torturas y malos tratos, y los que no lo hacen, acercándose a situaciones de seria impunidad ${ }^{38}$. Si esta actitud falla o es débil, se mina de manera directa la estabilidad democrática y se desnaturaliza la misma obligación que se asume, tal como reflejan varias sentencias del TEDH, en las que se afirma rotundamente que si no se investiga de manera eficaz siempre que alguna persona denuncia de manera defendible haber sufrido algún tipo de maltrato a manos de la policía o de funcionarixs del Estado, se vuelve completamente ineficaz la propia prohibición de la tortura ${ }^{39}$.

Y, aunque el concepto de impunidad implica actuaciones amplias y complejas, un indicador relevante, preocupante e inexplicable en un país democrático moderno, son los otorgamientos de indultos

\footnotetext{
${ }^{36}$ Sumando a las ya mencionadas, la STS 1202/1995-RJ 1995, 8879; STS 701/2001-RJ 2001, 3567; STS 294/2003-RJ 2003, 4381; STS 481/2003-RJ 2003, 3490; STS 457/2003-RJ 2003, 8929; STS 1122/1998-RJ 1998\7370; STS 489/2003-RJ 2003\4007 y STS 1218/2004RJ $2004 \backslash 8007$.

${ }^{37}$ Entre otras, STC 137/1990; STC 224/2007, STC 34/2008, STC 52/2008, STC 69/2008, STC 107/2008, STC 40/2010, STC 63/2010, STC 131/2012, STC 153/2013; STC 130/2016; STC 144/2016 que incluso cita jurisprudencia de TEDH.

${ }^{38}$ La imposición de sentencias leves favorece un clima de impunidad. Por ello, "las autoridades no deberían dudar en transmitir, a través de una declaración formal al nivel político más elevado, un claro mensaje: es necesario establecer una política de «tolerancia cero» de la tortura y otras formas de malos tratos". Como afirma VILLALIBRE FERNÁNDEZ, Vanesa, "Confluencia del Derecho a la Tutela Judicial Efectiva con el concepto de «investigación oficial eficaz» en el contexto de la prohibición de la tortura”, Foro Nueva época, vol. 15, núm. 1, 2012, pp. 29-86, especialmente p. 76.

${ }^{39}$ Caso Beristain Ukar c. España, de 8 de marzo de 2011 (Demanda No 40351/05) párrafo 28 y 29, por ejemplo, y el resto de las 10 condenas a España.
} 
a personas condenadas por tortura o malos tratos ${ }^{40}$. En este sentido, en España se han producido algunos casos de indultos a personas condenadas por tortura o malos tratos que fueron muy criticados, tanto dentro del Estado como internacionalmente. Entre ellos, el más representativo y polémico resulta el doble indulto realizado en 2012 a cuatro mossos d'Esquadra que habían sido condenados por torturar a una persona extranjera y hemofílica a la que habían confundido con un atracador, y que prosperaron en contra de los informes de los jueces de la Audiencia de Barcelona que había dictado la sentencia condenatoria y de la Fiscalía. Indultos que les acaban permitiendo el reingreso al cuerpo policial ${ }^{41}$. La oposición más destacable a estos indultos la protagonizaron 180 jueces de toda España en un Manifiesto en el que valoraban que estos indultos eran arbitrarios e ilegítimos, representaban un ejercicio abusivo de las funciones que tiene el Estado para otorgar indultos, implicaban una actuación contra la dignidad humana, e incumplían la obligación que le incumbe al Estado "de perseguir cualquier acto de tortura, sobre todo cuando es realizado por agentes a su servicio" y la valoraban "impropia de un sistema democrático de derecho, ilegítima y éticamente inasumible" y con efectos devastadores para la sociedad ${ }^{42}$.

Otro tema relevante vinculado a la impunidad es la camaradería entre compañerxs funcionarixs, policiales o penitenciarios, que incluye el deber de actuar entre pares o el deber de actuar del superior, conocido como espíritu de cuerpo y que el Tribunal Supremo ha tratado en diferentes sentencias, condenando por el artículo $176 \mathrm{CP}$ cuando compañeros policías presencian los malos tratos y no los impiden, y más aún cuando es un superior ${ }^{43}$. Acciones que tienen diversas consecuencias, desde obstaculizar investigaciones que conduzcan al castigo de los culpables hasta permitir de manera directa tratos degradantes o torturas. La imposibilidad de disponer de pruebas para las investigaciones y las condenas es clave, lo reconocen todas las sentencias del TEDH que condenan a España por violación

\footnotetext{
${ }^{40}$ CARRACEDO CARRASCO, Eva, Pena e indulto: una aproximación holística, Madrid, Thomson Reuters Aranzadi, 2018.

${ }^{41}$ La Audiencia de Barcelona condenó a tres mossos por delito de torturas y lesiones agravadas a 6 años y 7 meses de cárcel, y al otro a 2 años y 3 meses de prisión por delito contra la integridad moral. El Tribunal Supremo confirma la condena por tortura, pero disminuye la sanción a 3 de ellos por no considerar el agravante de ensañamiento. El primer indulto les rebaja la pena de prisión a dos años y sustituye la inhabilitación por la suspensión, permitiendo el reingreso en el cuerpo. La Audiencia Provincial de Barcelona acuerda, entonces, el cumplimiento de la pena que quedaba tras el indulto, pero el Gobierno concede un nuevo indulto sustituyendo la pena de prisión por multa. Ver AP de Barcelona, sección 9, Sentencia 20 de noviembre 2008, ARP/2009/28 y STS 1246/2009-RJ/2009/5963.

${ }^{42}$ Manifiesto denominado Contra el indulto como fraude. En defensa de la independencia judicial y de la dignidad, firmado el 29 de noviembre de 2012 por 180 jueces de toda España, jueces de Instrucción, Penales, Sociales, Mercantiles, Contenciosos Administrativos, Magistrados de Audiencias Provinciales, de Tribunales Superiores de Justicia, de la Audiencia Nacional y del Tribunal Supremo.

${ }^{43}$ Como exponen diversas sentencias tales como STS 726/2001-RJ 2001, 3572; STS 1559/2003-RJ 2003, 9246, STS 294/2003-RJ 2003, 4381 y STS 662/1999-RJ/1999/4867. Ver MUÑOZ SÁNCHEZ, JUAN, Los delitos contra la integridad moral, citado, p. 77 y TAMARIT SUMALLA, José María, "De las torturas y otros delitos contra la integridad moral", citado, p. 859 y confrontar con artículo 5.2 de la Ley Orgánica 2/1986, de 13 de marzo, de Fuerzas y Cuerpos de Seguridad (LFCSE).
} 
procesal de la prohibición de tortura del artículo 3 del Convenio Europeo. Pero hay un caso que no llegó a Estrasburgo y que ejemplifica de manera brutal los casos de extrema impunidad que pueden darse en democracia y de mayor vulnerabilización étnico racial, de sexo género y de clase, especialmente relevantes en tortura y malos tratos. Es el caso de una mujer extranjera, negra y trabajadora sexual que sufrió extrema violencia sexual mientras estaba detenida en Bilbao por agentes de la Brigada Policial de Extranjería de la policía nacional. Hechos probados en sentencia de la Audiencia Provincial de Vizcaya de 1998 y por el Tribunal Supremo en 1999, quien entendió que era incompatible con un Estado de Derecho que un hecho tan gravísimo de violación acreditada y constatada quedara impune por "trasnochadas ideas corporativas o falso compañerismo"44.

No deja de llamar la atención, también, las explicaciones que se suelen realizar ante casos de maltrato en el marco de detenciones. La jurisprudencia del Tribunal Supremo, del Tribunal Constitucional y sentencias del Tribunal Europeo de Derechos Humanos muestran las reiteradas explicaciones justificativas de que los maltratos se produjeron en el contexto de la "violencia permitida" en una detención o como "respuesta a la violencia de la detención", incluso en casos con resultado de muerte $^{45}$. Igualmente en las 10 sentencias del TEDH que condenan a España por violación de la vertiente procesal en relación al artículo 3 del Convenio Europeo de Derechos Humanos, especialmente la última donde los relatos probados de los hechos de la detención resultan tan desmesurados y violentos que motivan la única sentencia que condena a España por trato inhumano y degradante ${ }^{46}$.

En efecto, el ejercicio de la violencia estatal para ser legítimo también está sujeto a límites, como los que establece la Ley Orgánica 2/1986, de 13 de marzo, de Fuerzas y Cuerpos de Seguridad del Estado (LFCSE), tanto dependientes del Gobierno de la Nación como los Cuerpos de Policía de las Comunidades Autónomas y los dependientes de las Corporaciones Locales. La Ley insiste en el hecho de que todas las

\footnotetext{
${ }^{44}$ El 4 de junio de 1998 la Audiencia Provincial de Vizcaya considera probado que Rita Rogerio había sido golpeada y violada cuando se encontraba bajo custodia policial, pero absuelve a los 3 agentes implicados porque ninguno de ellos aporta pruebas contra sus compañeros. El Tribunal Supremo, en sentencia de 21 de abril de 1999, solicita a la Audiencia que investigue adecuadamente el caso y castigue a los culpables. Pero en un nuevo juicio, el 22 de mayo de 2000, los policías imputados fueron absueltos por faltas de pruebas y se remite a investigación policial interna, donde la Unidad de Asuntos Internos de la Dirección General de la Policía concluyó que no había existido agresión ni falta administrativa alguna. STS 662/1999-RJ/1999/4867 y AMNISTÍA INTERNACIONAL, Informe España: crisis de identidad. Tortura y malos tratos de índole racista a manos de agentes del Estado, Madrid, 2002, pp. 46-47 y AMNISTÍA INTERNACIONAL, Está en nuestras manos. No más violencia contra las mujeres, Madrid, 2004, pp. 115-116.

${ }^{45}$ Por ejemplo, en sentencias del Tribunal Supremo: STS 2051/2002-RJ 2003/1117; STS 1725/2001-RJ 2001, 8851; STS 701/2001-RJ 2001, 3567; STS 1326/1998-RJ 1998, 8569 y STS 1644/2002-RJ 2002, 8881.
}

${ }^{46}$ Sentencia del TEDH Portu Juanenea y Sarasola Yarzabal c. España (Demanda nº 1653/13) de 13 de febrero de 2018. 
fuerzas y cuerpos de seguridad del Estado tienen que adecuarse al ordenamiento vigente, cumplir sus funciones con absoluta neutralidad política e imparcialidad y sin discriminación alguna por razón de raza, religión u opinión, absteniéndose de cualquier acto de corrupción y sujetando su actuación profesional a los principios de jerarquía y subordinación, sin que la obediencia debida pueda ser razón que justifique delitos (artículo 2 y 5.1). Y establece como principios básicos de actuación el impedir cualquier práctica abusiva, arbitraria o discriminatoria que entrañe violencia física o moral, actuando eficazmente para evitar un daño grave, inmediato e irreparable, debiendo regirse por los principios de congruencia, oportunidad y proporcionalidad en la utilización de los medios a su alcance. Especificando que "solamente deberán utilizar las armas en las situaciones en que exista un riesgo racionalmente grave para su vida, su integridad física o las de terceras personas, o en aquellas circunstancias que puedan suponer un grave riesgo para la seguridad ciudadana" (artículo 5.2). En relación a los detenidxs, recuerda que los miembros de las Fuerzas y Cuerpos de Seguridad siempre velarán por la vida e integridad física de las personas a quienes detuvieren o que se encuentren bajo su custodia, respetando el honor y la dignidad de las mismas (artículo 5.3). Por lo tanto, resultan inadmisibles las excusas que impliquen una violencia o uso de la fuerza física en la detención que no respete los principios de oportunidad, necesidad y proporcionalidad, eligiendo el instrumento menos lesivo posible y proporcional al daño que se intenta evitar $^{47}$.

\section{Las condenas del Tribunal Europeo de Derechos Humanos.}

España ha sido condenada por el Tribunal Europeo de Derechos Humanos-TEDH en 10 ocasiones por violación del artículo 3 del Convenio Europeo para la Protección de los Derechos y de las Libertades Fundamentales-CEDH, la primera en noviembre de 2004 y la última en febrero de 2018. Cronológicamente, los casos son los siguientes: Martínez Sala c. España, de 2 de noviembre de 2004 (Demanda N ${ }^{\circ}$ 58438/00), San Argimiro Isasa c. España, de 28 de septiembre de 2010 (Demanda N 2507/07), Beristain Ukar c. España, de 8 de marzo de 2011 (Demanda No 40351/05), B. S. c. España, de 24 de julio de 2012 (Demanda No 47159/08), Otamendi Egiguren c. España, de 16 de octubre de 2012 (Demanda No 47303/08), Etxebarria Caballero c. España, de 7 de octubre de 2014 (Demanda No

\footnotetext{
47 También hay Instrucciones que explican claramente los límites, como la Instrucción 12/2007 del Secretario de Estado de Seguridad español sobre los comportamientos exigidos a los miembros de las fuerzas y cuerpos de seguridad del Estado para garantizar los derechos de las personas detenidas o bajo custodia policía y la Instrucción núm. 4/2018, de la Secretaría de Estado de seguridad por la que se aprueba la actualización del protocolo de actuación en las áreas de custodia de detenidos de las fuerzas y cuerpos de seguridad del Estado, de 22 de septiembre de 2018.
} 
74016/12), Ataun Rojo c. España, de 7 de octubre de 2014 (Demanda No 3344/13), Arratibel Garciandia c. España (Demanda No 58488/13) de 5 de mayo de 2015 y Beortegui Martínez c. España, de 31 de mayo de 2016 (Demanda No 36286/14) y la sentencia de 13 de febrero de 2018, en el caso Portu Juanenea y Sarasola Yarzabal c. España (Demanda No 1653/13).

Las 10 sentencias condenan a España en su vertiente procesal, que implica insuficiencia de la investigación oficial de denuncias de torturas y malos tratos, y en un caso, la última sentencia, también condena en su vertiente material, cuando se considera que efectivamente hubo malos tratos, como tratos inhumanos y degradantes y/o tortura; ya que la prohibición de la tortura del Convenio Europeo de Derechos Humanos implica, no sólo el aspecto sustancial de la prohibición del acto lesivo en sí, sino también el aspecto procesal que exige la investigación adecuada, eficaz y oportuna de las denuncias sobre maltratos $^{48}$. De las 10 sentencias, en 8 los demandantes son hombres y en 2 son mujeres, en 9 casos los demandantes son españoles y en uno es una mujer extranjera. En 9 sentencias se alega haber sufrido los malos tratos mientras estaban detenidxs incomunicados vinculados a terrorismo de ETA o relacionado, mientras que en un caso los hechos se vinculan a maltrato policial sin detención a una mujer que ejercía la prostitución. Estas condenas resultan altamente relevantes en la lucha contra la tortura y en la consolidación democrática, aunque llama la atención y es criticable, que la justicia española no haya hecho eco considerable de las mismas actualizando la doctrina y la jurisprudencia interna, y que no reproduzca la obligación de condenar por torturas y malos tratos considerando la doble vertiente procesal y sustantiva $^{49}$. Y que tampoco tuvieran una gran acogida política y de la ciudadanía en términos de claro rechazo a las conductas condenadas. La reacción, en algunos casos, fue mantener la noticia de la condena fuera del foco mediático y del debate político, sin pretender tampoco extraer conclusiones enriquecedoras, prácticas judiciales, penitenciarias y políticas preventivas para evitar nuevos casos de malos tratos o tortura. Y, en otras, se negó la premisa mayor minimizando el hecho concreto de la condena.

\footnotetext{
${ }^{48}$ FERNÁNDEZ DE CASADEVANTE, Carlos, "La obligación de investigación efectiva en el Derecho Internacional de los Derechos Humanos. Especial referencia a la práctica española”, Revista electrónica de estudios internacionales, No 26, 2013, pp. 1-42 y VILLALIBRE FERNÁNDEZ, Vanesa, "Confluencia del Derecho a la Tutela Judicial Efectiva con el concepto de «investigación oficial eficaz» en el contexto de la prohibición de la tortura”, citado, pp. 57-79 y pp. 82-86.

49 Ídem, pp. 32-56. Sobre el impacto de las condenas del TEDH, ver CISNEROS TRUJILLO, Cástulo, "La prohibición de tratos inhumanos y degradantes en las detenciones policiales o de agentes del Estado en España”, Revista Derecho del Estado, № 44, septiembre-diciembre de 2019, pp. 161-193, especialmente pp. 179-189.
} 
En efecto, la sensación es que lejos de ser una llamada de atención al Tribunal Supremo o al Tribunal Constitucional e, incluso, a la propia justicia ordinaria y a las fuerzas y cuerpos de seguridad del Estado y a la sociedad toda, las condenas parecieron más ofender que avergonzar al Estado español. Y preocupa aún más cuando constatamos que, para elaborar estas sentencias, el TEDH consideró distintos Informes del CPT y del Comisario de derechos humanos del Consejo de Europa, en los cuales desde el 2001 se comunicaba a España de situaciones anómalas vinculadas a personas en régimen de detención incomunicada y que deberían ser modificadas. Con carácter general el TEDH recuerda en todas las condenas a España que cuando un individuo afirma de manera argumentada haber sufrido tortura o malos tratos según el artículo 3 del CEDH, en manos de la policía o de otros servicios equiparables del Estado, éste tiene un deber general e inexcusable impuesto por el art. 1 del CEDH de realizar una investigación oficial eficaz. Y que la noción de recurso efectivo implica que el Estado está obligado a realizar investigaciones en profundidad cuyo fin sea llegar a esclarecer la verdad jurídica del hecho en cuestión, y la eventual identificación y castigo de los responsables. Especialmente el TEDH mostraba preocupación por la situación de particular vulnerabilidad de las personas detenidas en régimen de incomunicación en España, particularmente de personas acusadas de delitos de pertenencia a grupos terroristas, y exige como contraprestación un riguroso sistema de prevención de todo abuso policial ${ }^{50}$.

Señalaré seguidamente los aspectos más relevantes de las sentencias que condenan a España por el artículo 3 del CEDH, primero los 8 casos de condena en su vertiente procesal vinculados a terrorismo, luego el caso de la condena donde la demandante es una mujer nigeriana que ejercía la prostitución y, finalmente, el décimo y, hasta el momento último caso, la sentencia que considera que también hubo violación material y condena a España por trato inhumano y degradante.

La primera condena a España fue por el caso Martínez Sala c. España, de 2 de noviembre de 2004 (Demanda $\mathrm{N}^{\mathrm{o}}$ 58438/00), en el cual los demandantes fueron detenidos incomunicados durante 11 días por la guardia civil producto de una investigación vinculada al terrorismo poco antes de los Juegos Olímpicos celebrados en Barcelona, como sospechosos de pertenecer a un movimiento separatista catalán, y donde los demandantes denuncian que sufrieron torturas, tanto físicas como psicológicas, y trato inhumano y degradante. El TEDH acabó condenando por primera vez a España por falta de

\footnotetext{
${ }^{50}$ Ver MIRALLES RUIZ-HUIDOBRO, Rocío, “Informe el Tiempo de los Derechos: La jurisprudencia del Tribunal Europeo de Derechos Humanos relativa a España por torturas. Del terrorismo a la criminalización de la disidencia”, en SAURA, J. (coord.), Papeles: El Tiempo de los Derechos, Huri-Age Consolider-Ingenio 2010, No 31, septiembre 2013, pp. 1-45.
} 
investigación oficial real respecto a las denuncias de tortura y malos tratos, provocando un relevante impacto al romper la sensación de impunidad en la llamada lucha contra el terrorismo interno ${ }^{51}$. Los criterios que utiliza la condena para valorar si una investigación ha sido efectiva según la $\mathrm{CEDH}$, muy relevantes para la jurisprudencia posterior, se basan en exigir que la investigación debe permitir determinar si el recurso a la fuerza estaba o no justificado en las circunstancias y demostrar que se han tomado medidas razonables y exhaustivas para asegurar la obtención de las pruebas relativas a los hechos en cuestión (párrafos 156 a 160).

En San Argimiro Isasa c. España, de 28 de septiembre de 2010, (Demanda No 2507/07), la segunda condena a España, el demandante fue detenido en Madrid en mayo de 2002 por causas vinculadas a pertenencia a banda armada, terrorismo, tenencia de armas y explosivo y tentativa de asesinato. La sentencia concluye que no puede afirmar con certeza que las lesiones que presentaba el demandante eran producto de violencia desproporcionada en el momento de la detención o por malos tratos en los interrogatorios, pero recuerda dos Informes enviados al Gobierno español después de la visita del Comité Europeo para la Prevención de la Tortura y las penas o los tratos inhumanos o degradantes del Consejo de Europa ${ }^{52}$, donde se exponía que las personas detenidas en régimen incomunicado también debían tener el derecho a ser examinadas por un médico de su elección, que podrá efectuar su examen en presencia del médico oficial nombrado por el Estado. Sin embargo, España no sólo no acató esta recomendación, sino que el mismo CPT comprueba que, en la inmensa mayoría de los casos, los médicos forenses tampoco utilizaban los formularios recomendados, ni siquiera, la versión vigente del formulario protocolario. Así, el TEDH no puede establecer más allá de toda duda razonable, que el demandante haya estado sometido a malos tratos y esa "imposibilidad emana, en gran parte, de la ausencia de una investigación en profundidad y de forma efectiva por parte de las autoridades nacionales en respuesta a la denuncia de malos tratos presentada por el demandante" (párrafo 65). Y refiere, como lo hará en sentencias posteriores, que "es consciente de las dificultades que un detenido puede encontrar para aportar pruebas de los malos tratos sufridos durante su detención incomunicada, particularmente cuando se trata de alegaciones de actos de malos tratos que no dejan rastro" (párrafo 63), manifestando

\footnotetext{
${ }^{51}$ RUILOBA ALVARIÑO, Julia, "La sentencia del TEDH en el asunto Martínez Sala y otros c. España, 2 de noviembre de 2004. Crónica de una muerte anunciada", Revista Española de Derecho Internacional, Vol. 57, No 1, enero a junio 2005, pp. $209-220$.

52 De 13 de abril de 2000 en relación a la visita de noviembre-diciembre de 1998 con recomendaciones sobre los formularios utilizados por los médicos forenses y el Informe de 13 de marzo de 2003 de la visita realizada en julio de 2001, ya citados.
} 
que es precisamente esta misma violación de las responsabilidades del Estado español las que imposibilitan valorar si efectivamente se produjeron malos tratos.

En Beristain Ukar c. España, de 8 de marzo de 2011 (Demanda No 40351/05) el TEDH reproduce los argumentos comentados en la sentencia anterior, destacando que el demandante, detenido en septiembre de 2002 en San Sebastián por su presunta participación en altercados callejeros violentos (kale borroka) y con detención incomunicada, alega malos tratos y tortura que implican gran violencia, que incluyen golpes, bolsa en la cabeza para asfixia, graves vejaciones sexuales, amenazas de muerte y violación. Y señala que los informes de los médicos forenses no dan parte de lesiones, pese a que en todos se indicaba que el demandante se había quejado de haber sufrido malos tratos (párrafo 30), y recuerda que cuando un individuo afirma de manera defendible haber sufrido, a manos de la policía o de otros servicios comparables del Estado, malos tratos graves, el Estado debe organizar una investigación oficial efectiva ${ }^{53}$.

El caso Otamendi Egiguren c. España, de 16 de octubre de 2012 (Demanda № 47303/08) es especialmente peculiar, por la profesión del demandante y porque el mismo fue absuelto por la Audiencia Nacional, en un fallo que coincide con los fundamentos de la posterior sentencia del TEDH, afirmando que España no investigó de manera adecuada y exhaustiva las denuncias de tortura y malos tratos. El demandante es de profesión periodista, director de un diario, y es arrestado en 2003 y puesto en detención preventiva incomunicada en el marco de una investigación judicial en relación con presuntos delitos de pertenencia y colaboración con la organización terrorista ETA. En todas sus comparecencias declaró, en presencia de un abogado de oficio, haber sido objeto de severos malos tratos durante su detención preventiva, haber recibido amenazas de muerte y violencias varias. La sentencia recuerda que la situación de vulnerabilidad particular de las personas detenidas en régimen de incomunicación “justifica la toma de medidas de vigilancia jurisdiccional apropiadas, previstas por la Ley de Enjuiciamiento Criminal para los casos de detención incomunicada, con el fin de que los abusos sean evitados y que la integridad física de los detenidos sea protegida" (párrafo 41).

\footnotetext{
${ }^{53}$ El TEDH afirma que "si no fuera así, a pesar de su fundamental importancia, la prohibición legal general de la tortura y de las penas o tratos inhumanos o degradantes sería ineficaz en la práctica y sería posible, en algunos casos, que agentes del Estado pisotearan, gozando de una casi impunidad, los derechos de los sometidos a su control" (párrafo 28).
} 
La sexta condena, Etxebarria Caballero c. España, de 7 de octubre de 2014 (Demanda n ${ }^{\circ}$ 74016/12), corresponde a un caso especialmente delicado por ser la demandante una mujer que denuncia excesivo maltrato y violencia en la detención y también durante su incomunicación, con amenazas, episodios de asfixia con bolsas de plástico en la cabeza, violación y diversos abusos sexuales de gran violencia, interrogatorios estando desnuda y vendada, luego de haber sido detenida por la Guardia Civil en una investigación judicial por su presunta participación en diversos delitos de terrorismo. En la sentencia condenatoria, el TEDH destaca diversos Informes que habían denunciado previamente la situación de torturas y malos tratos que se estaban constatando en España, como los Informes del CPT dirigidos al Gobierno español de 2013, el Informe de 2013 del Comisario de Derechos Humanos del Consejo de Europa, el Informe de la Defensora del Pueblo de 2012, y los del Comité contra la Tortura y el del Comité de Derechos Humanos de Naciones Unidas, ya comentados. Antecedentes que, sumados a las anteriores sentencias condenatorias a España, "indican una serie de brechas en el sistema actual, tales como la falta de exámenes forenses diligentes e independiente de los detenidos incomunicados, lo cual conduce a investigaciones ineficaces de las alegaciones de malos tratos infligidos por las fuerzas del orden" (párrafo 32). El TEDH entiende que la carencia de pruebas que constata la Audiencia Nacional en la demanda de malos tratos presentada, se debe a que la demandante se encontraba en régimen detenida incomunicada y, por ende, imposibilitada para recabar ningún tipo de prueba. E insiste que cuando un individuo afirma de manera argumentada haber sufrido malos tratos de manos de la policía o de otros servicios equiparables del Estado, debe existir una investigación oficial efectiva para identificar y castigar a los responsables (párrafo 43), “consciente de las dificultades con las que un detenido se puede encontrar para aportar pruebas de malos tratos padecidos mientras estaba en régimen de detención incomunicada, especialmente cuando se trata de alegaciones de unos actos de malos tratos que no dejan huella, como los denunciados por la demandante" (párrafo 57).

En el séptimo caso, Ataun Rojo c. España (Demanda no 3344/13), de 7 de octubre de 2014, el demandante también se encontraba detenido en régimen de incomunicación por delito de terrorismo, y el TEDH repite los argumentos expuestos para condenar; sorprendiéndose del auto de 10 de febrero de 2011 del Juez de Instrucción No 4 de Pamplona que sobresee provisionalmente estas denuncias de malos tratos porque "en ausencia del 'más mínimo indicio de criminalidad' la identificación y el interrogatorio de los agentes de policía que hubieran estado en contacto con el demandante serian inútiles y 'únicamente 
servirían para exponer la identidad de quienes trabajan en labores de lucha antiterrorista y oír sus previsibles negaciones a lo imputado’ (párrafo 18).

La octava condena a España se basa en el caso Arratibel Garciandia c. España (Demanda n ${ }^{\circ}$ 58488/13) de 5 de mayo de 2015, similar a los anteriores, con denuncia de malos tratos durante su detención en 2011 en régimen de incomunicación en el marco de una investigación judicial acerca de un presunto delito de pertenencia a la organización EKIN, del grupo terrorista ETA. Denuncia grave violencia y violencia sexual, incluyendo unas declaraciones que realizó el demandante en presencia de un abogado de oficio y dos guardias civiles, donde firma con la palabra "Aztnugal", que significa "ayuda" en euskera escrito al revés (párrafo 14). Citando diversas sentencias propias para reforzar la idea central de la obligación del gobierno de investigar de manera clara y decidida las denuncias de malos tratos contrarios al artículo 3 del Convenio ${ }^{54}$, valora que la investigación de la denuncia de maltrato no se ha desarrollado con el suficiente detenimiento ni efectividad que exige el Convenio; ya que "los medios de prueba adicionales sugeridos por el demandante... hubieran podido contribuir al esclarecimiento de los hechos, en un sentido o en otro, tal como lo exige la jurisprudencia del TEDH” (párrafo 39).

En el caso Beortegui Martínez c. España, de 31 de mayo de 2016 (Demanda no 36286/14) el demandante denuncia graves malos tratos sufridos durante su detención preventiva en régimen de incomunicación en 2011 por la Guardia Civil debido a una investigación judicial sobre un presunto delito de pertenencia a la organización terrorista ETA. Denuncia severos malos tratos y torturas durante su traslado a Madrid, incluyendo maltrato sexual. Consta que una de sus declaraciones, el 21 de enero de 2011, se realizó de madrugada "en presencia de un abogado designado de oficio, al que habrían puesto detrás de él y al cual no podía ver, y de una persona que llevaba un pasamontaña y de un Guardia Civil con la cabeza descubierta" (párrafo 12). En la condena, el TEDH recuerda todas las anteriores sentencias condenatorias; agregando que lo severo de los maltratos que denuncia del demandante hubieran merecido una detenida investigación por parte del Estado de manera más exhaustiva que la que se realizó para desestimar su pretensión. Y aclara que ya se ha pronunciado sobre la tardanza de los demandantes en

\footnotetext{
${ }^{54}$ Como las sentencias McCann y otros c. Reino Unido, 27 de septiembre de 1995 (Demanda No 18984/91), Dikme c. Turquía, 11 de julio de 2000 (Demanda N²0869/92), y las españolas comentadas como Beristain Ukar, Otamendi, Etxebarria Caballero, Ataun Rojo, entre otras.
}

CEFD Número 43 (2020) I ISSN: 1138-9877 I https://doi.org/10.7203/CEFD.43.17577 
interponer denuncia por maltrato o tortura en otras sentencias ${ }^{55}$, porque "las consecuencias psicológicas de los malos tratos inferidos por agentes del Estado pueden también ir en perjuicio de la capacidad de las víctimas de quejarse de los tratos padecidos, y constituir, de esta manera, un obstáculo mayor al ejercicio del derecho a reparación de las víctimas de torturas y de otros malos tratos”, impidiendo que la víctima sea incapaz de iniciar los trámites necesarios para emprender acciones contra el autor de los hechos de manera inmediata (párrafo 43).

La siguiente sentencia que analizamos por violación del artículo 3 del Convenio en su vertiente procesal es, en realidad, la cuarta condena del TEDH a España, y presenta particularidades destacables. Es el caso B. S. c. España, de 24 de julio de 2012 (Demanda No 47159/08), la demandante es la primera mujer que consigue una condena a España por violación del artículo 3 del Convenio, siendo además la primer persona extranjera y sobre unos hechos no vinculados al terrorismo, sino que se refieren a maltrato policial sin detención de una mujer de origen nigeriano que residía legalmente en España y por un altercado vinculado al ejercicio de la prostitución en la vía pública en 2005 en Palma de Mallorca. La sentencia condena a España por violación del artículo 3 en su vertiente procesal y por violación del artículo 14 del Convenio sobre prohibición de discriminación. Luego de los hechos, la demandante presenta denuncia y acude a un centro médico donde constatan lesiones leves, pero el Juzgado de Instrucción No 9 de Palma de Mallorca decreta el sobreseimiento provisional y archivo del caso. Según refiere la sentencia del TEDH, la demandante interpone recurso por la actitud discriminatoria de los policías y solicita medidas de investigación tendentes a probarlo, como identificación de los agentes y testimonio de los testigos, pero el Juzgado desestima el recurso alegando que esos procedimientos policiales "no tienen otro objeto que impedir el bochornoso espectáculo de la prostitución en la vía pública" (párrafo 14). La Audiencia Provincial de Baleares estima parcialmente el recurso en 2007, revoca el sobreseimiento y ordena realizar ante el Juzgado de Instrucción un juicio de faltas contra los dos policías responsables del hecho, pero no se llevó a cabo ningún otro medio de prueba de cargo y se acaba absolviendo a los policías. El TEDH estima claramente, y con argumentos que repetirá en posteriores sentencias, que el Estado español incumplió sus obligaciones de realizar una investigación oficial efectiva con identificación y castigo de los responsables, lo que hace ineficaz en la práctica a la

55 Velev c. Bulgaria, de 16 de abril de 2013 (Demanda No 43531/08) (párrafos 59-60) y en el caso Mocanu y otros c. Rumania, 17 de septiembre de 2014, (Demanda No 10865/09, 45886/07 y 32431/08), (párrafo 251-255 y 265). Ver también la Observación general núm. 3 del Comité contra la tortura de las Naciones Unidas, 2012, ap. 38. 
prohibición legal general de la tortura y de las penas o tratos inhumanos y degradantes; ya que los agentes del Estado podrían pisotear con impunidad los derechos de los sujetos sometidos a su control (párrafo 40). El TEDH considera que los propios informes médicos aportados en la causa justificaban la investigación de los hechos (párrafos 45 y 46), sumando no sólo de la presencia efectiva de lesiones en la demandante como consta en los informes médicos, sino también las supuestas palabras racistas y degradantes vertidas en su contra. Por ello, condena vinculando ambas violaciones del Estado español, la prohibición de discriminación del artículo 14 del Convenio y la violación en la vertiente procesal del artículo 3, condenando por no investigar adecuadamente la denuncia de maltrato y la denuncia de discriminación; ya que los órganos jurisdiccionales internos españoles "no tuvieron en cuenta la vulnerabilidad específica de la demandante, inherente a su condición de mujer africana ejerciendo la prostitución” (párrafo 71).

Finalmente, la última condena que ha recibido España, hasta el momento, del TEDH por violación del artículo 3 del Convenio, ha tenido un gran impacto por la gravedad de los hechos realizados por los demandantes, que son condenados el 21 de mayo de 2010 por la Audiencia Nacional por delito de estragos, dos delitos de asesinato terrorista y 48 asesinatos en grado de tentativa como autores del atentado de la Terminal 4 del aeropuerto de Madrid-Barajas el 30 de diciembre de 2006, y porque es la primera vez que se condena a España por violación de la prohibición de que nadie podrá ser sometido a tortura ni a penas o tratos inhumanos o degradantes en los aspectos material y procesal. Se trata del caso Portu Juanenea y Sarasola Yarzabal c. España, de 13 de febrero de 2018 (Demanda N 1653/13), donde los demandantes denuncian a España por torturas y malos tratos en el momento de su arresto y durante la detención preventiva en 2008, en el País Vasco, por un grupo especializado en la lucha contra el terrorismo de la Guardia Civil. Los demandantes denuncian haber sufrido serias torturas que corroboran los informes médicos, tanto en la detención, en el traslado y mientras estaban detenidos, detallando lesiones muy graves como golpes severos, fracturas, intentos de ahogamiento en un río y amenazas de muerte, que requirieron medicación y cuidados especiales, uno de ellos con tratamiento de hospitalización en cuidados intensivos (párrafos 17 a 24). En 2010, la Audiencia Provincial de Guipúzcoa condena a 4 guardias civiles por tortura y lesiones y absuelve a los otros 11 agentes, en un juicio donde se consideran probado los graves maltratos a los detenidos con el propósito de castigarles por su pertenencia a ETA, considerando que no había indicios de que hubieran mentido por el simple hecho de su pertenencia a ETA o por alguna estrategia en particular, y que los guardias civiles condenados habían 
actuado con total impunidad (párrafo 44 y 45). Pero los guardias civiles recurrieron en casación al Tribunal Supremo que revocó la sentencia recurrida y les absolvió, cuestionando la declaración de los demandantes como una estrategia de ETA de denuncias falsas de tortura ${ }^{56}$. Llegados al TEDH, la sentencia da un salto sustancial en relación a las anteriores condenas a España, desde una perspectiva más incluyente y protectora, y les condena por violación material de la prohibición contenida en el artículo 3 del Convenio por constatar tratos inhumanos y degradantes, junto con la condena por la vertiente procesal de falta de investigación adecuada y suficiente ${ }^{57}$. La sentencia puntualiza que las lesiones de los demandantes se produjeron mientras estaban en manos de la Guardia Civil, y que España no ha aportado argumentos convincentes ni creíbles para explicar o justificar las lesiones sufridas por los demandantes, lo que conduce al TEDH de manera inexorable a imputarles las mismas (párrafo 82$)^{58}$.

Por consiguiente, como queda patente en las 10 sentencias que condenan a España, es altamente preocupante no cumplir con la obligación asumida internacionalmente de investigar de manera adecuada y exhaustiva el círculo vicioso de indefensión que vincula las dos esferas de la valoración del artículo 3 del CEDH como realiza el TEDH, la procesal y la sustantiva. Es el propio proceso de investigación obligado del Estado el que puede realmente permitir valorar si hubo malos tratos o tortura, ya que los demandantes están imposibilitados o tienen mayores dificultades para gestionar y obtener medidas probatorias, incluso un abogado o un médico de su elección, y más aún cuando están incomunicados. Así, violada la obligación de la investigación exhaustiva y oportuna, muy poco (o nada) queda por hacer en términos probatorios en relación a la valoración de la tortura sustantiva por el TEDH, debido a la mala investigación realizada por el Estado y no porque tenga real convencimiento que esos malos tratos o tortura no han existido, sino porque no puede probarlos, como explica en las propias sentencias. Sin partes de médicos forenses debidamente completados, estando en régimen de incomunicación

\footnotetext{
${ }^{56}$ STS 1136/2011-RJ 2012\1378, donde el Tribunal Supremo utiliza como prueba contundente un documento secuestrado a un jefe militar de ETA detenido en Francia y declara que "nos transmite sin ningún género de dudas la falacia de las torturas" (párrafo 20). Resalta que "la insinceridad... de los querellantes deja huérfana de toda prueba la causación de las lesiones sufridas por los terroristas, ignorando si hubo excesos en las detenciones" (párrafo 24).

${ }^{57}$ Remite a la calificación jurídica de jurisprudencia anterior para valorar la diferencia entre tortura y tratos inhumanos. Ver Selmouni $c$. Francia, 28 de julio de 1999 (Demanda No 25803/94) donde estableció que el carácter grave de los sufrimientos "depende del conjunto de circunstancias del caso, especialmente de la duración de los malos tratos y de sus consecuencias físicas o psíquicas, así como, en ocasiones, del sexo, la edad o el estado de salud de la víctima" (párrafo 71 y 72).

${ }^{58}$ Aunque la sentencia fue dictada por unanimidad, hay 3 de los 7 magistrados que emitieron en conjunto un voto particular parcialmente disidente y parcialmente concordante, en el que consideran que el maltrato probado debería ser calificado como tortura. Y están en desacuerdo con el voto mayoritario porque trasladan la carga de la prueba de las torturas a los propios demandantes, contrario a la jurisprudencia del Tribunal "que es muy protectora de la dignidad de las personas, aun cuando hayan cometido actos cobardes y odiosos" (párrafo 17, del voto particular).
} 
imposibilitado de poder exteriorizar la denuncia y sin abogado y médico de parte, y con un Estado reacio a investigar y, esencialmente, renuente a creer en las denuncias de tortura, los casos al TEDH llegan muy debilitados para poder obtener una sentencia condenatoria sustancial, aún en casos de graves maltratos. Existe, sin duda, una relación clara y directa entre la vertiente procesal y la vertiente material de la prohibición de la tortura que se materializa en la vulnerabilidad en la que se encuentran las personas detenidas y las posibilidades (imposibilidades) que las mismas tienen para obtener las pruebas que necesitan ${ }^{59}$. Por ende, las violaciones del aspecto procesal manifiestan una potencialidad perversa, porque en ellas participan de manera directa o indirecta no sólo las fuerzas y cuerpos de seguridad implicadas como responsables de los maltratos, sino también el resto de profesionales que participan de distintas maneras en la detención o prisión de las personas, como médicos forenses, abogados de oficio, fiscales y los propios jueces y altos tribunales. La tortura y los maltratos no pueden desarrollarse aislados de una trama institucional, judicial y política que la permita y ampare. Por consiguiente, afirmar que el TEDH solo ha condenado a España en la fase procesal, no debería funcionar como aliciente y menos como excusa.

\section{Las deudas (democráticas) pendientes.}

No hay nada más antisistema y más inconstitucional que practicar, tolerar, justificar, no investigar adecuada y exhaustivamente, o no condenar de manera tajante todo y cualquier maltrato, trato inhumano, degradante o tortura. La lucha contra el terrorismo, nacional o internacional, las estrategias de seguridad nacional, los efectos de la pobreza y la exclusión social de gran parte de lxs internxs y detenidxs por el proceso de criminalización de la pobreza y la criminalización de la inmigración, los deterioros del Estado Social español y todas las consecuencias de las políticas económicas neoliberales que implican restricciones de derechos y de garantías por recortes presupuestarios no pueden jamás justificar ni legitimar prácticas de malos tratos o tortura. No hay excusas para estas prácticas ni están justificadas o permitidas bajo ninguna circunstancia excepcional, como lo establece la propia Convención contra la Tortura y el carácter erga omnes de la regulación. Resulta imprescindible y urgente, entonces, porque son a la vez posibles y oportunos, realizar algunos apuntes para el futuro inmediato, acciones que puedan

\footnotetext{
${ }^{59} \mathrm{El} \mathrm{TEDH}$ incluso ha manifestado que debería entenderse una inversión de la carga de la prueba, en Berktay c. Turquía de 1 de marzo de 2001 (Demanda No 22493/93) y en Portu Juanenea y Sarasola c. España. Consultar LÓPEZ GUERRA, Luis María, "El derecho a la verdad: ¿la emergencia de un nuevo derecho en la jurisprudencia del tribunal europeo de derechos humanos?", Anuario iberoamericano de justicia constitucional, $\mathrm{N}^{\mathrm{o}} 22,2018$, pp. 11-30.
} 
fortalecer las estrategias de condena a la tortura, retomando en gran medida las recomendaciones y comentarios que realizan los Informes de Organismos Internacionales y ONG, las sentencias internacionales y nacionales y la doctrina.

El más fortalecedor apunte es, sin duda, el de fomentar medidas educativas, de sensibilización y deontológicas con el objetivo de eliminar la tortura, tratos degradantes o cualquier maltrato, dejando claro al personal que custodia a las personas detenidas que los maltratos físicos, el uso excesivo de la fuerza y la agresión verbal no son aceptables ni están justificados en ninguna circunstancia. Que deben adoptarse las medidas adecuadas para mejorar la capacidad del personal de prisiones a la hora de manejar situaciones de alto riesgo con el fin de no tener que recurrir al uso de la fuerza innecesariamente, ofreciéndoles formación sobre maneras de evitar situaciones de crisis y apaciguar las tensiones, así como para la utilización de métodos seguros de control y contención. Resulta imprescindible que las fuerzas y cuerpos de seguridad del Estado tengan completo convencimiento que tienen prohibido, en cualquier situación respecto a las personas detenidas y que tienen bajo su responsabilidad, maltratarles de ninguna manera, tanto física como psicológicamente. Trabajar la concienciación de que la gestión de la violencia entre lxs presxs y con el personal penitenciario y policial es parte del deber de cuidado y que desatenderlo, y más aun de manera deliberada, implica, al menos, maltrato o trato degradante. Y extender medidas de educación en derechos humanos y de sensibilización social a toda la ciudadanía, con el fin de generar consenso democrático respecto a la prohibición de la tortura, rechazo unánime respecto a quienes la practican y conciencia ciudadana del deber de denuncia de todo hecho de maltrato, trato degradante o tortura.

A la vez, resulta imprescindible concienciar que los servicios sanitarios de los centros de detención, prisiones, CIE y comisarías en general pueden contribuir (o no) de manera significativa a la prevención de los malos tratos a los detenidxs mediante el registro sistemático de lesiones y, cuando proceda, a la comunicación de los hechos a las autoridades competentes. Las autoridades españolas deben asegurarse de que todo el personal sanitario de las prisiones o lugares de detención sean conscientes de su obligación de registrar e informar adecuada y exhaustivamente sobre las denuncias de malos tratos que reciban. Además, debería realizarse un registro especial sobre traumatismos en el que quedaran anotados todos los tipos de lesiones que se encuentran en los centros de detención, para identificar patrones abusivos y poder prevenirlos. Para ello, lxs profesionales sanitarixs (y los internxs y detenidxs) no deben estar expuestos a ninguna clase de presión indebida o represalia por parte del personal directivo. 
Igualmente, es indispensable que las personas detenidas, incluso las personas en régimen de incomunicación, puedan realmente ejercer su derecho a la defensa y a la tutela efectiva, disponiendo de abogadx de su elección, pudiendo realizar llamadas a familiares o grupos de referencia, disfrutando del acceso a salud, atención médica, recursos sanitarios y medicinales adecuados, garantizando, en todo momento, el pleno ejercicio de los derechos humanos de las personas que se encuentren detenidas o privadas de libertad, particularmente en relación con grupos en situación de vulnerabilidad ${ }^{60}$. Adoptando, para ello, medidas para disminuir las situaciones de vulnerabilización de mujeres, niñxs, personas con discapacidad, minorías étnicas, culturales o religiosas, personas con diversidad funcional, personas transgénero y LGTBIQ+, migrantes, extranjerxs, solicitantes de asilo, entre otros. Sin olvidar las medidas estructurales en todo centro de detención, como el tamaño de las celdas, luz natural y ventilación, acceso a sanitarios, actividades recreativas y educativas, garantizando condiciones adecuadas de limpieza y mantenimiento general, acorde a las condiciones climatológicas y al desarrollo de la cotidianeidad de las personas detenidas.

Relacionado al uso de técnicas para detención y privación de la libertad, se recomienda encarecidamente eliminar la fijación mecánica, especialmente a objetos fijos. La sujeción sólo debe realizarse con el fin de evitar que la persona detenida se haga daño a sí mismo y/o a terceros, únicamente como último recurso y nunca como un castigo. La sujeción debe aplicarse durante el menor tiempo posible, nunca en posición prona, y siempre bajo supervisión permanente de un profesional de la salud y con registro específico. A la vez, se debe reducir el tiempo de permanencia en régimen de aislamiento disciplinario como castigo por infracciones disciplinarios, y eliminarlo para los menores de edad y personas con especial vulnerabilidad. Igualmente, disminuir los cacheos minuciosos frecuentes y que impliquen el desnudo sistemático o conlleven un grave riesgo de trato degradante, garantizando la revisión de los criterios de necesidad y proporcionalidad en los mismos, a fin de asegurar el respeto de la dignidad personal, entre otras medidas recomendadas por los Organismos internacionales e Informes al respecto.

\footnotetext{
${ }^{60}$ En este sentido, ver NACIONES UNIDAS, Informe de Juan E. Méndez, Relator Especial sobre la tortura y otros tratos o penas crueles, inhumanos o degradantes en relación a las Reglas Mínimas para el Tratamiento de los Reclusos, A/68/295, de 9 de agosto de 2013 y Informe de Juan E. Méndez, Relator Especial sobre la tortura y otros tratos o penas crueles, inhumanos o degradantes en relación a la denegación de tratamientos médicos, A/HRC/22/53, de 1 de febrero de 2013.
} 
Es necesario, sin duda, que los órganos de gobierno, órganos judiciales, autoridades policiales y de las fuerzas y cuerpos de seguridad del Estado español o penitenciarias, tramiten de manera urgente y adecuada las denuncias presentadas por cualquier maltrato y realicen exhaustivamente las debidas investigaciones con todas las garantías, obligando la presencia habitual de los responsables en las áreas de detención y su contacto directo con las personas detenidas, la introducción de estrategias de supervisión, control y vigilancia continuada (como las cámaras de grabación) y la formación del personal penitenciario y las fuerzas y cuerpos de seguridad del Estado, en el que quede radicalmente claro a todos lxs agentes que cualquier forma de maltrato, incluido el comportamiento irrespetuoso hacia las personas detenidas resulta inaceptable y será sancionado debidamente. Los órganos de gobierno, judiciales y legislativos deben mantener una postura sin contemplaciones frente a la tortura como el mayor obstáculo de la democracia y a quienes la practican como enemigos del sistema democrático. No tolerarlos, denunciarlos, apartarlos de los cargos de autoridad, juzgarlos con todas las garantías y legislar para prohibir los indultos en casos de sentencias por tortura o tratos degradantes. Es preciso, entonces, realizar reformas legislativas, acciones políticas y desarrollo de políticas públicas oportunas y necesarias para fortalecer las instituciones encargadas de prevenir la tortura, especialmente el MNPT español, mejorar la técnica legislativa del CP español y modificarlo para cubrir las exigencias internacionales respecto a la prohibición de la tortura y de los tratos degradantes, como poner fin al aislamiento como medida disciplinaria para lxs menores y los colectivos más vulnerabilizados.

Por ende, es esencial que como sociedad asumamos el compromiso tajante y sin contemplaciones frente a la mayor lacra que tenemos como Estado Democrático. Que tomemos la labor de fiscalización ciudadana de defensa de las estructuras democráticas para no permitir ni legitimar con acción u omisión, apoyo político o con el voto a quienes recurren a la tortura $\mathrm{u}$ otros tratos o penas crueles, inhumanos o degradantes, ni a quienes las alientan, justifican, legitiman o indultan. Que entendamos, realmente y sin contemplaciones, que no existe ninguna justificación para la tortura y que ésta siempre representa la más grave afrenta al sistema democrático y constitucional que disfrutamos. 


\section{Bibliografía.}

Bibliografía general.

BECK, Urich, Sobre el terrorismo y la guerra, Madrid, Paidós Asterisco, 2003.

BUTLER, Judith, “El modelo Guantánamo”, El Viejo topo, No 178, 2003, pp. 59-69.

CARRACEDO CARRASCO, Eva, Pena e indulto: una aproximación holística, Madrid, Thomson Reuters Aranzadi, 2018.

CISNEROS TRUJILLO, Cástulo, "La prohibición de tratos inhumanos y degradantes en las detenciones policiales o de agentes del Estado en España”, Revista Derecho del Estado, No 44, septiembre-diciembre de 2019, pp. 161-193.

DEL BURGO, Myriam, “Guantánamo. Violación de los derechos humanos”, Quadernos de criminología: revista de criminología y ciencias forenses, $\mathrm{N}^{\circ}$ 9, 2010, pp. 38-43.

DÍAZ PITA, María del Mar, "El bien jurídico protegido en los nuevos delitos de tortura y atentado contra la integridad moral", Estudios Penales y Criminológicos, № 20, 1997.

ESCUDERO ALDAY, Rafael, "Jaque a la Transición: análisis del proceso de recuperación de la memoria histórica", Anuario de Filosofia del Derecho, 2013 (XXIX), pp. 319-340.

ESCUDERO ALDAY, Rafael, Memoria histórica y democracia en España. La brecha de la Transición, México, Fontamara, 2016.

FERNÁNDEZ DE CASADEVANTE, Carlos, "La obligación de investigación efectiva en el Derecho Internacional de los Derechos Humanos. Especial referencia a la práctica española”, Revista electrónica de estudios internacionales, $\mathrm{N}^{\circ}$ 26, 2013, pp. 1-42.

GALVÁN RODRÍGUEZ, Eduardo, "La noche más oscura y el secreto inquisitorial” en FERNÁNDEZ RODRÍGUEZ, M., BRAVO DÍAZ, D., MARTÍNEZ PEÑAS, L. (coord.), Una década de cambios: de la guerra de Irak a la evolución de la primavera árabe (2003-2013), Madrid, Asociación Veritas para el Estudio de la Historia, el Derecho y de las Instituciones, 2013, pp. 83-98.

GARCÍA CÍVICO, Jesús, "La doble ineficacia de la tortura”, Cuadernos Electrónicos de Filosofía del Derecho, Número 34, 2016, pp. 134-161.

GARCÍA CÍVICO, Jesús, La tortura. Aspectos jurídicos, sociales y estéticos-culturales, Valencia, Tirant lo Blanch, 2019.

LA TORRE, Massimo, “Amistades peligrosas. Tortura y Derecho”, Derechos y Libertades, № 28, Época II, enero 2013, pp. $25-38$.

LA TORRE, Massimo y LALATTA COSTERBOSA, Marina, ¿Legalizar la tortura? Auge y declive del Estado de Derecho, trad. de Ansuátegui Roig F., Valencia, Tirant Lo Blanch, 2018.

LÓPEZ GUERRA, Luis María, "El derecho a la verdad: ¿la emergencia de un nuevo derecho en la jurisprudencia del tribunal europeo de derechos humanos?", Anuario iberoamericano de justicia constitucional, № 22, 2018, pp. 11-30.

MARIÑO MENENDEZ, Fernando y CEBADA ROMERO, Alicia (dir.), La creación del mecanismo español de prevención de la tortura, Madrid, Iustel, 2009.

MIRALLES RUIZ-HUIDOBRO, Rocío, "Informe el Tiempo de los Derechos: La jurisprudencia del Tribunal Europeo de Derechos Humanos relativa a España por torturas. Del terrorismo a la criminalización de la disidencia", en SAURA, J. (coordinador), Papeles: El Tiempo de los Derechos, Huri-Age Consolider-Ingenio 2010, № 31, septiembre 2013, pp. 1-45.

MUÑOZ CONDE, Francisco, Derecho Penal. Parte Especial, Valencia, Tirant lo Blanch, 2002.

MUÑOZ SÁNCHEZ, Juan, Los delitos contra la integridad moral, Valencia, Tirant lo Blanch, 1999.

ORTEGA GUERRA, Benjamín, “Biopolítica de la tortura: Guantanamizar Irak”, Opera, No 8, pp. 7-55.

CEFD Número 43 (2020) I ISSN: 1138-9877 I https://doi.org/10.7203/CEFD.43.17577 
ORTIZ DE URBINA, Iñigo, “Sobre el delito de tortura en el CP español”, inédito, 2018.

PÉREZ ROYO, Javier, Terrorismo, democracia y seguridad, en perspectiva constitucional, Madrid, Marcial Pons, 2010.

PETERS, Edward, La Tortura, traduc. Míguez, N., Madrid, Alianza, 1985.

PINO GAMERO, Esther, "El sistema de prevención de la tortura del Protocolo Facultativo a la Convención contra la Tortura", Universitas. Revista de Filosofia, Derecho y Política, No 18, Julio 2013, pp. 3-39-

RIBOTTA, Silvina, "Sobre el Protocolo Facultativo a la Convención contra la Tortura y su regulación en el derecho español. Mejor prevenir que castigar", ICADE. Revista de las Facultades de Derecho y Ciencias Económicas y Empresariales, $\mathrm{N}^{0}$ 85, 2012, pp. 153-180.

RIBOTTA, Silvina, "La Tortura en la Constitución española”, en DE LUCAS, J. y RODRÍGUEZ URIBES, J.M. (editores), $L a$ Constitución de 1978 y los derechos humanos, Valencia, Tirant lo Blanch, 2018, pp. 413-446.

REVUELTA, Manuel, Herrera de la Mancha: Un caso ejemplar. Sumario 22/79, Madrid, Ediciones de la Piqueta, 1980.

RUILOBA ALVARIÑO, Julia, "La sentencia del TEDH en el asunto Martínez Sala y otros c. España, 2 de noviembre de 2004. Crónica de una muerte anunciada”, Revista Española de Derecho Internacional, Vol. 57, No 1, enero a junio 2005, pp. 209-220.

RUIZ-HUERTA, Alejandro, Los ángulos ciegos: Una perspectiva crítica de la transición española, 1976-1979, Madrid, Biblioteca Nueva, 2008.

SÁNCHEZ SOLER, Mariano, La transición sangrienta. Una historia violenta del proceso democrático en España (19751983), Barcelona, Península, 2010.

SAVATER, Fernando y MARTÍNEZ FRESNEDA, Gonzalo, Teoría y presencia de la tortura en España, Barcelona, Anagrama, 1982.

TAMARIT SUMALLA, Josep María, "De las Torturas y otros delitos contra la integridad moral" en QUINTERO OLIVARES, G. (Director) y MORALES PRATS, F. (Coordinador), Comentarios al Código Penal Español. Tomo I (Artículos I a 233), Navarra, Thomson Reuters-Aranzadi, 2011, 6º edición, pp. 1059-1092.

TOMÁS Y VALIENTE, Francisco, "La última etapa y la abolición de la tortura judicial en España", Anales de la Facultad de Derecho, No 1,1963 , pp. 23-60.

TOMÁS Y VALIENTE, Francisco, “García Valdés y Herrera de la Mancha”, Diario 16, 29 octubre 1979.

TOMÁS Y VALIENTE, Francisco, La tortura en España, Barcelona, Ariel, 1994.

VILLALIBRE FERNÁNDEZ, Vanesa, "Confluencia del Derecho a la Tutela Judicial Efectiva con el concepto de «investigación oficial eficaz» en el contexto de la prohibición de la tortura”, Foro Nueva época, vol. 15, núm. 1, 2012, pp. $29-86$.

ZÚÑIGA RODRÍGUEZ, Laura, "El tipo penal de tortura en la legislación española, a la luz de la jurisprudencia nacional e internacional”, UNIVERSITAS VITAE homenaje a Ruperto Núñez Barbero, Universidad de Salamanca, 2014, pp. 898-945.

Informes

AMNISTÍA INTERNACIONAL, Informe España: crisis de identidad. Tortura y malos tratos de indole racista a manos de agentes del Estado, Madrid, 2002.

AMNISTÍA INTERNACIONAL, Está en nuestras manos. No más violencia contra las mujeres, Madrid, 2004.

AMNISTÍA INTERNACIONAL, Informe 2017/2018 Amnistía Internacional. La situación de los derechos humanos en el mundo, Londres, 2018.

COLECTIVO 36, Libro blanco de las cárceles franquistas, Barcelona, Planeta, 2012.

CEFD Número 43 (2020) I ISSN: 1138-9877 I https://doi.org/10.7203/CEFD.43.17577 
COMISARIO DE DERECHOS HUMANOS DEL CONSEJO DE EUROPA, Informe de 9 de octubre de 2013 luego de la visita a España en junio de 2013.

CONSEJO DE EUROPA, Informe Comisario para los Derechos Humanos del Consejo de Europa - Nils Muižnieks, tras su visita a España, del 3 al 7 de junio de 2013, de 9 de octubre de 2013.

CONSEJO DE LA ABOGACÍA EUROPEA-CCBE, Tribunal Europeo de Derechos Humanos. Preguntas y respuestas para los abogados, 2012.

COORDINADORA PARA LA PREVENCIÓN Y DENUNCIA DE LA TORTURA, La tortura en el Estado español. Recopilación de las denuncias por tortura, violencia institucional y tratos inhumanos, crueles o degradantes recogidos durante el año 2017 en el Estado español, mayo 2018.

CPT, Informe para el Gobierno español sobre la visita llevada a cabo en España por el Comité Europeo para la Prevención de la Tortura y de las Penas o Tratos Inhumanos o Degradantes (CPT) por la visita efectuada en julio de 2001, 13 de marzo del 2003.

CPT, Informe para el Gobierno español sobre la visita llevada a cabo en España por el Comité Europeo para la Prevención de la Tortura y de las Penas o Tratos Inhumanos o Degradantes (CPT), por la visita efectuada en diciembre de 2005, del 10 de julio de 2007

CPT, Informe para el Gobierno español sobre la visita llevada a cabo en España por el Comité Europeo para la Prevención de la Tortura y de las Penas o Tratos Inhumanos o Degradantes (CPT), por las visitas realizadas entre mayo y junio de 2011, del 30 de abril de 2013.

CPT, Informe para el Gobierno español sobre la visita llevada a cabo en España por el Comité Europeo para la Prevención de la Tortura y de las Penas o Tratos Inhumanos o Degradantes (CPT) del 27 de septiembre al 10 de octubre de 2016.

DEFENSOR DEL PUEBLO, Informe 2012, Madrid, 2013.

DEFENSOR DEL PUEBLO, Informe monográfico Estudio sobre los partes de lesiones de las personas privadas de libertad, Madrid, mayo 2014.

FUNDACIÓN ABOGACÍA ESPAÑOLA, Informe España ante la tortura y los malos tratos de noviembre, Madrid, 2016.

HUMAN RIGHT WATCH, Informe Human Right Watch 2017, NY, 2018.

MECANISMO NACIONAL ESPAÑOL DE PREVENCIÓN DE LA TORTURA-DEFENSOR DEL PUEBLO, Informe anuales 2016, Madrid, 2017.

MECANISMO NACIONAL ESPAÑOL DE PREVENCIÓN DE LA TORTURA-DEFENSOR DEL PUEBLO, Informe anuales 2018, Madrid, 2019.

NACIONES UNIDAS, Informe de Juan E. Méndez, Relator Especial sobre la tortura y otros tratos o penas crueles, inhumanos o degradantes en relación a las Reglas Mínimas para el Tratamiento de los Reclusos, A/68/295, de 9 de agosto de 2013.

NACIONES UNIDAS, Informe de Juan E. Méndez, Relator Especial sobre la tortura y otros tratos o penas crueles, inhumanos o degradantes en relación a la denegación de tratamientos médicos, A/HRC/22/53, de 1 de febrero de 2013.

NACIONES UNIDAS, Informe de Pablo de Greiff, Relator Especial sobre la promoción de la verdad, la justicia, la reparación y las garantías de no repetición, en la Misión España, A/HRC/27/56/Add.1, de 22 de julio de 2014.

SOS RACISMO, Informe anual 2017. Sobre el racismo en el Estado español, Donostia/San Sebastián, 2017. 